\title{
Matematiikan parhaat osaajat lukion lopussa ja heidän matematiikka-asenteissaan tapahtuneet muutokset
}

\author{
Laura Niemi ${ }^{1}$, Jari Metsämuuronen ${ }^{2}$, Markku S. Hannula ${ }^{1}$ ja Anu Laine ${ }^{1}$ \\ ${ }^{1}$ Helsingin yliopisto \\ ${ }^{2}$ Kansallinen koulutuksen arviointikeskus
}

Tutkimus perustuu Opetushallituksen ja Kansallisen koulutuksen arviointikeskuksen keräämään pitkittäisaineistoon. Samaan ikäluokkaan kuuluvat oppilaat ovat osallistuneet kansallisiin matematiikan kokeisiin ja matematiikkaasenteita kartoittaviin kyselyihin vuosien 2005-2015 aikana neljällä eri mittauskerralla perusopetuksen kolmannelta vuosiluokalta toisen asteen loppuun. Tutkimusaineiston kokonaisotos käsittää yhteensä 3896 oppilasta. Tutkimuksessa keskitytään tarkastelemaan matematiikassa parhaiten menestyneitä opiskelijoita. Matematiikan parhaiksi osaajiksi määritetään kansalliseen matematiikan kokeeseen osallistuneet lukiolaiset, jotka saivat pitkän matematiikan ylioppilaskokeesta arvosanan laudatur tai eximia cum laude approbatur $(n=146)$. Ensin tutkimuksessa selvitetään, miten parhaiden osaajien matematiikka-asenteet muuttuivat perusopetuksesta lukion loppuun ja toiseksi, miten opetuksen pedagogiset ratkaisut yläkoulussa ja lukiossa selittävät osaamiseltaan parhaiden tyttöjen ja poikien asenteissa tapahtuneita muutoksia. Selittävien tekijöiden analyysissa käytetään päätöspuuanalyysia (DTA) ja lineaarista regressioanalyysia. Matematiikan parhaiden osaajien matematiikasta pitäminen kasvoi lukio-opintojen aikana, mutta minäkäsitys ja kokemus matematiikan hyödyllisyydestä laskivat. Matematiikassa parhaiten menestyneiden tyttöjen asenteissa tapahtuneet muutokset poikkesivat asenteiden yleisestä muutossuunnasta. Parhaiden tyttöjen minäkäsitys kasvoi yläkoulun ja lukion aikana lähes parhaiten menestyneiden poikien tasolle ja tytöt pitivät matematiikasta lukion lopussa poikia enemmän. Matematiikassa parhaiten menestyneiden tyttöjen ja poikien asenteiden kehittymistä selittivät erilaiset opetuksen pedagogiset ratkaisut. Molemmilla myönteisiä asenteita vahvistivat yleisesti oppilaskeskeisyyteen, yhteistoiminnallisuuteen ja oppijoiden tarpeiden huomioimiseen liittyvät pedagogiset ratkaisut.

AVAINSANAT: matematiikan parhaat osaajat, pitkittäistutkimus, kansallinen arviointi, matematiikka-asenteet, toisen asteen koulutus 
Matematiikan opetuksen tavoitteena perusopetuksessa ja lukiossa on pitää yllä oppilaan innostusta ja kiinnostusta matematiikkaa kohtaan sekä tukea oppilaan myönteistä minäkuvaa ja itseluottamusta (Opetushallitus, 2004; 2014; 2015; 2019). Tämä ei kuitenkaan näyttäisi toteutuvan, sillä matematiikkaan liittyvät asenteet heikkenevät yleisesti perusopetuksen aikana. Tämä saattaa vaikuttaa oppilaiden toista astetta koskeviin koulutusvalintoihin ja myös tulevissa opinnoissa ja elämässä menestymiseen (Metsämuuronen, 2013). On esitetty myös huoli tyttöjen matematiikkaan liittyvästä itseluottamuksesta, joka laskee selvästi poikien minäpystyvyyttä alhaisemmaksi jo peruskoulun aikana (Tuohilampi \& Hannula, 2013; Metsämuuronen, 2017). Tässä tutkimuksessa on tarkoitus selvittää, miten matematiikkaan liittyvät asenteet kehittyvät perusopetuksesta lukion loppuun, kun tutkimuskohteena ovat matematiikassa parhaiten menestyneet opiskelijat.

Tutkimus perustuu Opetushallituksen ja Kansallisen koulutuksen arviointikeskuksen keräämään matematiikan oppimistuloksia käsittelevään pitkittäisaineistoon, jossa samaan ikäluokkaan kuuluvia oppilaita on seurattu perusopetuksen kolmannelta vuosiluokalta toisen asteen koulutuksen loppuun vuosien 2005-2015 aikana. Matematiikan parhaiksi osaajiksi määritetään lukioopiskelijat, jotka ovat menestyneet parhaiten pitkän matematiikan ylioppilaskokeessa. Aikaisempiin tutkimustuloksiin (Julin \& Rautopuro, 2016; Niemi ym., 2021) perustuen tiedetään, että opiskelijat, jotka suuntautuivat lukiossa pitkän matematiikan opiskeluun, menestyivät keskimäärin jo yhdeksännellä luokalla selvästi muita paremmin kaikilla matematiikan osa-alueilla ja suurin osa yhdeksännen vuosiluokan kokeessa parhaiten menestyneistä osaajista oli parhaita myös toisen asteen lopussa pidetyssä kokeessa. Toisaalta samaan tutkimusaineistoon perustuvien aikaisempien analyysien mukaan tiedetään, että erinomaiseen menestymiseen matematiikassa voi yltää myös keskitasoa heikommastakin lähtötasosta (Niemi ym., 2020). Emme ajattelekaan menestymistä matematiikassa synnynnäisenä ja muuttumattomana lahjakkuutena (ks. mm. Sternberg \& Davidson, 2005) vaan näemme matemaattisten taitojen olevan kehitettävissä (ks. mm. Leikin, 2014).

Opettajalla on tärkeä rooli oppilaiden myönteisten asenteiden edistämisessä. Esimerkiksi yhteistoiminnallisten opetusmenetelmien käytön on havaittu parantavan keskitasoa parempien osaajien matematiikkaan liittyviä asenteita ja näiden menetelmien käyttö on vaikuttanut erityisesti poikien myönteiseen asennekehitykseen (Hannula \& Oksanen, 2013). Tutkimuksen toisena tavoitteena 
onkin selvittää, millaiset opetuksen pedagogiset ratkaisut vahvistavat matematiikassa parhaiten menestyneiden opiskelijoiden matematiikka-asenteita. Matematiikan parhaiden osaajien asenteita koskeva tutkimus on vähäistä ja tällä tutkimuksella saadaan tietoa siitä, millaiset pedagogiset ratkaisut yläkoulussa ja lukiossa ovat tärkeimpiä, kun halutaan tukea matematiikassa parhaiten menestyneiden tyttöjen ja poikien myönteistä suhtautumista matematiikkaa kohtaan.

\section{Matematiikkaan liittyvät asenteet}

Matematiikkaan liittyviä asenteita ja niiden suhdetta osaamiseen voidaan tarkastella monesta eri näkökulmasta. Tämä tutkimus perustuu kansalliseen matematiikan oppimistulosten arviointiin, jossa oppilaiden matematiikka-asenteita kartoitettiin kolmella ulottuvuudella: matematiikasta pitäminen, käsitys itsestä matematiikan osaajana ja kokemus matematiikan hyödyllisyydestä (ks. Metsämuuronen, 2009).

Lukuisat tutkimukset ovat osoittaneet matematiikkaan liittyvien asenteiden ja matematiikan osaamisen välillä olevan positiivinen korrelaatio (mm. Bandura, 1986 lähtien; Hannula \& Laakso, 2011; Ma \& Kishor, 1997; Roesken ym., 2011). Vaikka asenteiden ja saavutusten välistä kausaliteettisuhdetta on tutkittu yhä enemmän, vuorovaikutuksen suunnasta on saatu ristiriitaisia tuloksia. PISA-aineistosta tehdyn analyysin perusteella suomalaisoppilailla osaamisen vaikutus minäpystyvyyteen on yksi suurimmista (Williams \& Williams, 2010). Suomalaisessa pitkittäistutkimuksessa oppilaiden matematiikan osaamisen on havaittu vaikuttavan minäpystyvyyden kehittymiseen koko peruskoulun ajan, mutta vastakkaissuuntainen vaikutus voimistuu vähitellen ollen peruskoulun loppuvaiheessa sen kanssa samalla tasolla (Hannula ym., 2014). Matematiikasta pitämisen tai matematiikan hyödyllisyyden kokemisen yhteyttä osaamiseen on tutkittu vähemmän. Ma ja Kishor (1997) saivat meta-analyysissaan tulokseksi, että matematiikasta pitäminen vaikuttaa osaamiseen, mutta vaikutus heikkenee opiskelijoiden iän myötä. Meta-analyysissa oli mukana 113 tutkimusta koskien perusopetuksen ja toisen asteen opintoja. Ma ja Xu (2004) puolestaan osoittivat, että toisen asteen opinnoissa matematiikan osaaminen selittää, miten hyödylliseksi oppilas kokee matematiikan.

Matematiikkaan liittyvien asenteiden on havaittu Suomessa heikkenevän kouluvuosien aikana. Aluksi heikkenee ensisijaisesti matematiikasta pitäminen alakoulun aikana ja sen jälkeen yläkoulussa minäpystyvyys (Metsämuuronen, 2013). Pitkittäistutkimuksessa oppilaat pitivät matematiikasta eniten ensimmäisellä mittauskerralla, kolmannen luokan alussa. Pitäminen heikkeni huomattavasti 
kolmannen ja kuudennen luokan välillä. Minäpystyvyys ei juurikaan muuttunut vielä kolmannelta luokalta kuudennelle, mutta se heikkeni huomattavasti yläkoulun aikana. Oppilaat kokivat matematiikan hyödyllisyyden korkeaksi kuudennella luokalla, mutta koettu hyödyllisyys heikkeni samanaikaisesti minäpystyvyyden tunteen kanssa yläkoulun aikana. Oppilaat alkavat iän myötä myös arvioida osaamistaan enemmän suhteessa muihin samassa ryhmässä opiskeleviin oppilaisiin (mm. Tuohilampi \& Hannula, 2013). Big fish, little pond -efekti selittää oppilaan minäpystyvyyden kokemisessa tapahtuneita muutoksia, kun hän vertaa omaa osaamistaan ryhmän keskimääräiseen osaamiseen. Jos oppilaan taidot ovat keskivertoa paremmat, hänen käsityksensä itsestä matematiikan osaajana paranee ja vastaavasti oppilaan, joka kokee taitonsa keskitasoa heikommaksi, käsitys itsestä osaajana heikkenee (Marsh ym., 2019; Holm ym., 2020).

Kansallisissa oppimistulosarvioinneissa asenteilla on havaittu olevan suuri merkitys opiskeluun toisen asteen koulutuksessa. Yhdeksännen luokan kokonaisasenne ja kokonaisosaaminen selittävät sekä lukioon hakeutumista että matematiikan kurssien määrää toisella asteella. Mitä parempaa opiskelijan osaaminen on 9. luokalla, sitä positiivisempi on hänen käsityksensä matematiikasta oppiaineena ja sitä todennäköisemmin hän valitsee lukio-opinnot ja pitkän matematiikan (Metsämuuronen, 2017).

Matematiikkaan liittyy vahvoja sukupuolittuneita stereotypioita, jotka määrittävät tyttöjen ja poikien käsityksiä itsestään matematiikan oppijoina jo varhain. Jo koulun alussa tytöt arvioivat olevansa poikia heikompia matematiikassa, vaikka tyttöjen ja poikien matematiikan taidoissa ei olekaan eroa (Cvencek ym., 2011; Lindberg ym., 2013). Myös Oppermann ja kanssakirjoittajat (2021) osoittivat tutkimuksessaan, että sukupuoli vaikuttaa matematiikan opiskeluintoon jo peruskoulun toisella ja kolmannella luokalla. Tutkimuksessa löydettiin kolme erilaista ryhmää, joissa poikia oli eniten ryhmissä, joissa matematiikka koettiin innostavana ja tyttöjä enemmän ryhmässä, jossa oppilaiden suhtautuminen opiskeluun oli korkea kaikissa oppiaineissa. Tyttöjen käsitykset omasta matematiikan osaamisesta heikkenevät poikia voimakkaammin kouluvuosien edetessä ja sukupuolten välinen ero kasvaa (Lindberg ym., 2013). Sukupuolierot matematiikkaan liittyvässä itseluottamuksessa olivat Suomessa suuremmat kuin monessa muussa PISA-tutkimusmaassa (Williams \& Williams, 2010). Tyttöjen kiinnostuksen matematiikkaan ja luonnontieteisiin on nähty viime vuosina kuitenkin lisääntyvän. Korkeakoulujen matematiikkaa painottava todistusvalinta on saanut enemmän naisia 
suorittamaan pitkän matematiikan ylioppilaskokeen. Vuonna 2020 jo yli puolet pitkän matematiikan hyväksytysti suorittaneista opiskelijoista oli naisia (Ylioppilastutkintolautakunta, 2021).

Lahjakkaiden oppilaiden asenteita on tutkittu melko vähän. Erdogan ja Yemenli (2019) selvittivät matemaattisesti lahjakkaiden viidesluokkalaisten asenteita matematiikkaa kohtaan oppilaiden kertomusten ja haastattelujen avulla. Tulosten mukaan enemmistöllä oppilaista oli matematiikkaan positiivinen ja melko vakaa asenne, joka kehittyi varhaisessa iässä. Salmela (2016) tutki laudaturylioppilaiden vahvuuksia selvittääkseen, miten vahvuuksia voidaan tukea. Hänen tuloksensa osoittivat, että lahjakkaita oppilaita yhdisti vahva koulumyönteisyys ja sitoutuneisuus. Salmelan tutkimat laudaturylioppilaat menestyivät hyvin koulussa alaluokilta ylioppilastutkintoon ja heidän opiskeluaan kuvasi sinnikkyys, omaaloitteisuus ja itseohjautuvuus.

\section{Opetuksellisten tekijöiden yhteys opiskeluasenteisiin}

Opettajan toiminnalla, opetuskäytännöillä ja vuorovaikutuksella on keskeinen merkitys oppilaiden opiskeluasenteiden kehittymiselle ja ylläpitämiselle (SalmelaAro, 2018). Perusopetuksen ja lukion opetussuunnitelmien (Opetushallitus, 2004; 2014; 2015; 2019) mukaan matematiikan opetuksen tulee tukea oppilaiden myönteistä asennetta matematiikkaa kohtaan ja myönteistä minäkuvaa matematiikan oppijoina. Opetuksen tulisi myös ohjata oppilaita ymmärtämään matematiikan hyödyllisyys omassa elämässään ja laajemmin yhteiskunnassa. Lisäksi yläkoulussa oppilasta tulisi ohjata kehittämään oppimaan oppimisen taitoja ja opiskeluvalmiuksia tulevia jatko-opintoja varten (Opetushallitus, 2004; 2014). Tutkijat (mm. Hannula \& Oksanen, 2013; Koskinen, 2016; Metsämuuronen, 2017) ovat tunnistaneet erilaisia tapoja toteuttaa näitä tavoitteita. Keskeisiä ulottuvuuksia asenteisiin vaikuttavassa pedagogiikassa ovat oppilaskeskeisyys, monipuolisten opetusmenetelmien käyttö ja oppijoiden tarpeiden huomioiminen opetuksessa.

Oppilaat suhtautuvat opiskeluun myönteisemmin, kun opetuksessa toteutetaan oppilaskeskeisyyttä eli oppilaat voivat itse vaikuttaa ja päättää tekemisestään ja tuntea yhteenkuuluvuutta muiden oppilaiden kanssa (Salmela-Aro, 2018; Ryan \& Deci, 2017). Yhteistoiminnallisten opetusmenetelmien on havaittu tuottavan kansallisessa oppimistulosarvioinnissa hyviä tuloksia sekä osaamisen että asenteiden suhteen (Hannula \& Oksanen, 2013). Se, että oppilaat neuvoivat toisiaan, paransi osaamiseltaan keskitasoa parempien oppilaiden asenteita. Lisäksi 
yhteistoiminnallisten menetelmien käyttö ja opettajan hyvä oppilaiden käyttäytymisen hallinta vaikuttivat voimakkaammin poikien myönteisempään asennekehitykseen. Myös laudaturylioppilaita tutkineen Salmelan (2016) mukaan opiskelijoiden vahvuuksia ja opintomenestystä tukee parhaiten opetus, jota ilmentävät muun muassa opiskelijakeskeisyys ja oppimisen yhteisöllisyys sekä palautteen antaminen ja kannustaminen. Yhteistoiminnalliset menetelmät noudattavat sosiokonstruktivistista oppimiskäsitystä, jolle myös perusopetuksen opetussuunnitelman perusteet (Opetushallitus, 2004; 2014) pohjautuvat.

Monipuolisten opetusmenetelmien käyttö tarkoittaa, että opiskelussa käytetään vaihtelevia työtapoja. Perusopetuksen opetussuunnitelman perusteissa (Opetushallitus, 2014) ohjataan luomaan oppimisympäristö, jossa konkretia ja välineet ovat osana matematiikan opiskelua. Opiskelua on itsenäisesti ja yhdessä, hyödynnetään oppimispelejä ja käytetään tieto- ja viestintäteknologiaa. Yhteistoiminnallisuuden lisäksi oppimisen tulisi siis olla mielekästä, jossa konkreettisuus ja kontekstuaalisuus tukevat ymmärtämistä (Koskinen, 2016). Innovatiivisten opetusmenetelmien käytön on havaittu tukevan perinteisiä opetusmenetelmiä paremmin oppilaiden myönteisten asenteiden kehittymistä (mm. Ogbuehi \& Fraser, 2007).

Oppijoiden tarpeiden ja yksilöllisten erojen huomioiminen opetuksessa on keskeistä positiivisen asennoitumisen vahvistamiseksi (mm. Bloom, 1984). Opetuksessa tulisi huomioida oppijoiden yksilölliset erot ja tarjota taitotason mukaisia haasteita. Vanttajan (2002) tutkimuksessa osa laudaturylioppilaista koki opiskelun liian helpoksi eikä opetus ja oppilaan taitotaso kohdanneet. Perusopetuksen opetussuunnitelman perusteiden (Opetushallitus, 2014) mukaan kaiken opetuksen pedagogisena lähtökohtana tulisi olla eriyttäminen, joka perustuu oppilaiden tarpeille ja mahdollisuuksille muun muassa edetä yksilöllisesti. Eriyttämiseen liittyy myös mahdollisuudet suunnitella itse opiskelua ja valita erilaisia työtapoja. Eriyttämällä tuetaan oppilaan itsetuntoa, motivaatiota ja turvataan oppimisen rauhaa (mts. 30). Mielekäs eriyttäminen taitotason mukaisesti parantaa asenteiden lisäksi myös oppilaan osaamistasoa (Metsämuuronen, 2017).

\section{Tutkimuskysymykset}

Tutkimuksessa on tarkoitus selvittää, miten matematiikan parhaiden osaajien matematiikkaan liittyvät asenteet muuttuvat perusopetuksesta lukion loppuun ja millaiset opetuksen pedagogiset ratkaisut selittävät asenteissa tapahtuneita 
muutoksia.

Tutkimuskysymykset ja niille asetut hypoteesit ovat seuraavat.

1. Miten matematiikan parhaiden osaajien matematiikkaan liittyvät asenteet muuttuvat perusopetuksesta lukion loppuun ja millaisia eroja tässä kehityksessä on tyttöjen ja poikien välillä?

Hypoteesi: Matematiikka-asenteiden tiedetään heikkenevän kouluvuosien myötä (mm. Metsämuuronen, 2013). Matematiikasta pitäminen laskee jo alakoulun aikana ja minäpystyvyys ja hyödyllisyyden kokeminen yläkoulun aikana (Tuohilampi \& Hannula, 2013). Oletamme näin tapahtuvan myös parhailla osaajilla. Big fish, little pond -efektin (Marsh ym., 2019; Holm ym., 2020) mukaan esitämme, että parhailla osaajilla minäpystyvyys keskimäärin heikkenee. Tyttöjen käsitykset omasta matematiikan osaamisesta heikkenevät poikia voimakkaammin (mm. Lindberg ym., 2013).

2. Millaiset opiskelijoiden raportoimat yläkoulun ja lukion aikaiset opetuksen pedagogiset ratkaisut ovat yhteydessä matematiikassa parhaiten menestyneiden tyttöjen ja poikien asenteissa tapahtuneisiin muutoksiin yhdeksänneltä luokalta lukion loppuun?

Hypoteesi: Yleisesti myönteisiä asenteita voidaan vahvistaa pedagogisilla ratkaisuilla, joissa keskitytään oppilaskeskeisyyteen ja yhteistoiminnallisuuteen, matematiikan käytännönläheisyyteen sekä oppijoiden yksilöllisiä tarpeita huomioiviin toimintamalleihin (Ryan \& Deci, 2017; Salmela-Aro, 2018; Hannula \& Oksanen, 2013; Salmela, 2016; Koskinen, 2016; Ogbuehi \& Fraser, 2007; Bloom, 1984; Vanttaja, 2002). Yhteistoiminnalliset menetelmät opetuksessa selittävät erityisesti pojilla asenteiden myönteistä kehittymistä (Hannula \& Oksanen, 2013). Oletamme näiden tekijöiden vahvistavan myös parhaiden osaajien matematiikkaasenteita.

\section{Tutkimuskohde}

Tutkimuksessa käytetään Opetushallituksen ja Kansallisen koulutuksen arviointikeskuksen keräämää aineistoa, jossa samaan ikäluokkaan kuuluvia oppilaita on seurattu vuosien 2005-2015 välisenä aikana perusopetuksen kolmannelta 
vuosiluokalta toisen asteen koulutuksen loppuun. Oppilaat ovat tehneet matematiikan osaamista kartoittavat kokeet 3. ja 6. luokan alussa, 9. luokan lopussa sekä ammatillisen koulutuksen tai lukiokoulutuksen lopussa. Lisäksi oppilaat ovat vastanneet matematiikan asenteita kartoittavaan kyselyyn ja heiltä on kerätty myös erilaista taustatietoa demografisiin tietoihin, yksilöön, kouluun ja kotitaustaan liittyen. Tutkimusaineisto on laaja ja kansallisesti edustava. Kokonaisaineisto käsittää yhteensä 3896 opiskelijaa puuttuvien havaintojen mallintamisen jälkeen (ks. Niemi ym. 2021, s. 20-21). Asennemuuttujien osalta puuttuvia arvoja ei korvattu. Näiltä osin aineisto käsittää 2048 opiskelijaa.

Tutkimuskohteena ovat matematiikan parhaat osaajat. Matematiikan parhaiksi osaajiksi määritetään tässä tutkimuksessa kansalliseen matematiikan kokeeseen toisen asteen lopussa osallistuneet lukiolaiset, jotka saivat pitkän matematiikan ylioppilaskokeesta arvosanan laudatur tai eximia cum laude approbatur (jatkossa lyhyemmin eximia). Parhaat osaajat olisi voitu valita myös kansallisen kokeen perusteella. Valtaosa kansallisen kokeen parhaista osaajista kirjoitti pitkän matematiikan ja menestyi erinomaisesti ylioppilaskokeessa. Kokonaisuudessaan arvioimme ylioppilastutkinnon antavan kansallista koetta todenmukaisemman kuvan opiskelijoiden osaamisen tasosta toisen asteen lopussa. Ylioppilastutkinnolla on suuri painoarvo jatko-opintojen kannalta ja opiskelijat panostavat siihen kansallista koetta enemmän. Tämä rajaus myös mahdollistaa paremmin opetuksellisten tekijöiden merkityksen selvittämisen, sillä heidän opiskelukokemuksensa toisella asteella ovat keskenään samankaltaisemmat kuin jos mukaan olisi otettu myös lyhyen matematiikan ja ammatillisen koulutuksen suorittajat.

Kaikkiaan kansalliseen kokeeseen osallistuneista 54 prosenttia oli lukiolaisia ja lukiolaisista pitkän matematiikan ylioppilaskokeen suoritti yhteensä 490 opiskelijaa (12,6 \% koko aineistosta ja 23,3 \% lukiolaisista.) Myös kaikkiaan keväällä 2015 ylioppilastutkintoon ilmoittautuneista opiskelijoista noin 23 prosenttia ilmoittautui pitkän matematiikan ylioppilaskokeeseen (Ylioppilastutkintolautakunta, 2021). Tutkimusaineiston keruussa toisen asteen osalta on jonkin verran katoa, mutta ikäluokasta on tavoitettu kuitenkin riittävän kattava määrä opiskelijoita maan eri osista, kuntatyypeistä ja kieliryhmistä (Metsämuuronen, 2017). Laudaturin tai eximian kirjoittaneita opiskelijoita oli yhteensä 146 (3,8 \% koko aineistosta ja 30,0 \% pitkän matematiikan kirjoittajista). Parhaista osaajista poikia oli $85(58,2 \%)$ ja tyttöjä $61(41,8 \%)$. 
Parhaiden osaajien vertailuryhmänä pidetään niitä lukiolaisia, jotka saivat pitkän matematiikan ylioppilaskokeessa muun arvosanan kuin eximia tai laudatur (jatkossa keskitason osaajat, $n=344$ ). Taulukossa 1 nähdään parhaiden ja keskitason osaajien kokonaispistemäärien eroja lukion lopussa pidetyssä kokeessa. Osaamista kuvaavat pistemäärät esitetään samalla asteikolla kuin PISA- ja TIMSS-tutkimuksissa. Tällä asteikolla osaamiseltaan keskitason oppilas saa noin 500 pistettä ja keskihajonta on 100 pistettä (ks. Metsämuuronen, 2017, s. 214-215).

Taulukko 1. Kansallisen kokeen kokonaispisteet toisen asteen lopussa

\begin{tabular}{|c|c|c|c|}
\hline Koepisteet & $\begin{array}{l}\text { Yo-kokeen } \\
\text { parhaat } \\
\text { osaajat } \\
(n=146)\end{array}$ & $\begin{array}{l}\text { Yo-kokeen } \\
\text { keskitason } \\
\text { osaajat } \\
(n=344)\end{array}$ & $\begin{array}{l}\text { Koko otos } \\
(n=3896)\end{array}$ \\
\hline Keskiarvo & 772,3 & 672,9 & 542,7 \\
\hline Minimi & 593,6 & 439,5 & 192,6 \\
\hline Maksimi & 934,6 & 832,9 & 934,6 \\
\hline Keskihajonta & 59,4 & 64,7 & 124,7 \\
\hline
\end{tabular}

\section{Tutkimuksessa käytettävät mittarit}

Opiskelijoiden osaamista ja asenteita kartoitettiin neljällä eri mittauskerralla heidän ollessaan 3, 6. ja 9. vuosiluokalla sekä kolme vuotta myöhemmin, jolloin tavoitetut opiskelijat olivat toiseen asteen opintojen loppuvaiheessa ammatillisessa koulutuksessa tai lukiossa. Lisäksi opiskelijoilta kerättiin mittauskerroilla erilaisia taustatietoja, joista tässä tutkimuksessa keskitytään tarkastelemaan opiskelijoiden raportoimia opetuksen pedagogisia ratkaisuja yläkoulussa ja lukiossa.

\section{Koetehtävät}

Osaamista kartoittavat kansallisten kokeiden tehtävät, arvosteluperusteet ja pisteytysohjeet on laadittu asiantuntijaryhmissä ja tehtäväsarjat on esitestattu. Tehtäväsarjoissa oli vaikeustasoltaan helppoja, keskivaikeita ja vaikeita osioita (ks. tarkemmat tiedot Metsämuuronen, 2009). Kokeiden tehtävät pohjautuvat perusopetuksen opetussuunnitelman perusteissa (Opetushallitus, 2004) sekä lukion opetussuunnitelman perusteissa (Opetushallitus, 2003) ja ammatillisen koulutuksen tutkintoperusteissa (Opetushallitus, mm. 2009) määriteltyihin matematiikan tavoitteisiin ja sisältöihin. 
Jotta eri koeversioiden tuloksia voidaan vertailla keskenään, kokeiden pistemäärät on vertaistettu eli saatettu yhteismitallisiksi osiovasteteoriaan (Item Response Theory) perustuvan IRT-mallituksen avulla (Rasch, 1960; Lord \& Novick, 1968). Vertaistamisessa on käytetty linkkitehtäviä, joiden avulla osioiden vaikeustasoa voidaan arvioida. Lukion ja ammatillisen koulutuksen kokeissa 78 prosenttia tehtävistä oli suoraan yhdeksännen luokan kokeesta ja osa tehtävistä oli mukana jo kuudennen ja kolmannen luokan kokeissa (ks. tarkemmin mm. Metsämuuronen, 2017, s. 213-214).

\section{Asennemittarit}

Asenteita kartoitettiin 15 osion Likert-asteikollisella mittarilla, joka pohjautuu laajalti käytettyyn Fenneman ja Shermanin (1976) matematiikka-asennemittariin. Käytetty asteikko oli viisiportainen kolmannen luokan versiota lukuun ottamatta. Asenteita kartoitettiin kolmatta luokkaa lukuun ottamatta kaikilla muilla luokka-asteilla kolmesta näkökulmasta: matematiikasta pitäminen, käsitys itsestä matematiikan osaajana ja matematiikan hyödyllisyyden kokeminen. Osiota matematiikan hyödyllisyydestä ei kysytty kolmannella luokalla. Osioista matematiikasta pitäminen, käsitys itsestä matematïkan osaajana ja matematiikan hyödyllisyys koottiin luokka-asteen kokonaisasennetta kuvaava summamuuttuja. Lopullisten summien asteikko skaalattiin uudelle asteikolle, jonka arvot vaihtelivat välillä $\mathrm{o}-4(\mathrm{O}-1=$ negatiivinen asenne, $2=$ neutraali asenne, $3-4=$ positiivinen asenne) (Metsämuuronen, 2017, s. 37).

Yhdeksännellä luokalla ja toisella asteella kerättiin asenteisiin liittyvää tietoa myös oppilaiden kokemasta matematiikka-ahdistuksesta ja toisella asteella matematiikan opiskeluun liittyvistä tunnetiloista (Metsämuuronen \& Tuohilampi, 2017). Tässä tutkimuksessa keskitytään matematiikan minäkäsityksen, matematiikasta pitämisen ja matematiikan hyödyllisyyden kokemisen osa-alueisiin, koska halutaan analysoida asenteissa tapahtuneita muutoksia ja näistä kolmesta löytyy tietoa kaikilta tutkituilta kouluasteilta. Eri vuosiluokkien asenteita vertailtaessa käytetään prosenttiosuuksia käytettyjen asteikkojen maksimipistemääristä.

\section{Opetuksen pedagogiset ratkaisut}

Opetuksen pedagogisia ratkaisuja on kysytty opiskelijoilta yhdeksännellä vuosiluokalla ja toisen asteen lopussa. Opiskelijat ovat arvioineet pedagogisten ratkaisujen toistuvuuden toteutumista viisiportaisella Likert-asteikolla $\quad(1=e i$ 
lainkaan, 2= harvoin, 3= joskus, $4=$ usein, $5=$ lähes aina .

Opetuksen pedagogisten ratkaisujen ryhmittelyyn käytettiin eksploratiivista faktorianalyysia. Siinä tutkitaan korrelaatiomatriisien rakennetta eli etsitään muuttujien kombinaatioista sellaista mallia, joka selittää parhaiten muuttujien välistä vaihtelua (Metsämuuronen 2011, s. 667). Lataukset estimoitiin suurimman uskottavuuden menetelmällä (Maximum likelihood) ja rotaatiomenetelmistä käytettiin vinokulmaista Oblimin-rotaatiomenetelmää, jossa sallitaan, että faktorit voivat korreloida keskenään (Jokivuori \& Hietala, 2007). Kun analyysin avulla löydettiin sopivat faktorit, ne nimettiin ja niiden perusteella muodostettiin summamuuttujat, joita käytetään myöhemmin tulosten analyyseissa. Tässä tutkimuksessa opetuksellisia tekijöitä haluttiin ryhmitellä paremmin ymmärrettäviksi kokonaisuuksiksi. Tulosten analyyseissa käytetään sekä näitä jäsennettyjä kokonaisuuksia että alkuperäisiä yksittäisiä muuttujia.

Yksittäisistä muuttujista muodostettiin eksploratiivisen faktorianalyysin avulla ryhmiä, jotta tunnistettaisiin yksittäisiä opetusmenetelmiä laajempia pedagogisia lähestymistapoja. Faktorianalyysi tehtiin tutkimusaineistolle, joka käsittää yhteensä 3896 opiskelijaa. Yhdeksännen luokan opetuksen pedagogisten ratkaisujen faktorianalyysi tehtiin 3455 opiskelijan vastausten perusteella ja toisen asteen lopun pedagogisten ratkaisujen faktorianalyysi 1934 opiskelijan vastausten perusteella.

Rotatoidussa faktorimatriisissa (taulukko 2) näkyvät yläkoulun tekijöihin liittyvät faktorit ja niille latautuneet muuttujat.

Taulukko 2. Rotatoitu faktorimatriisi yläkoulun aikaisista opetuksen pedagogisista ratkaisuista

\begin{tabular}{|c|c|c|c|}
\hline & 1 & 2 & 3 \\
\hline Oppilaat selittävät muille, miten ovat tehtävänsä ratkaisseet. & ,857 &,- 055 &,- 154 \\
\hline Pohditaan, onko tehtävän vastaus järkevä. &, 530 & ,095 & 105 \\
\hline Oppilaat neuvovat toisiaan. &, 519 &,- 070 & ,093 \\
\hline Oppilaat asettavat itselleen tavoitteita ja arvioivat edistymistään. & ,372 & 258 & 086 \\
\hline Tehdään projektitöitä. &,- 036 & 708 &,- 165 \\
\hline Oppilaat käyttävät tietokonetta. &,- 074 & ,565 &,- 062 \\
\hline Opitaan mittaamalla, rakentelemalla ja muulla tavoin tekemällä. & ,056 & ,550 & 118 \\
\hline Opiskellaan ryhmissä tai pareittain. & 077 & 386 & 073 \\
\hline Sovelletaan matematiikan taitoja arkielämän tilanteisiin. & 176 & ,333 & ,218 \\
\hline On yhteistä opetusta opettajan johdolla. & ,030 &,- 097 & ,525 \\
\hline $\begin{array}{l}\text { Opettaja ottaa huomioon opetukseen liittyvät oppilaiden ideat ja } \\
\text { toiveet. }\end{array}$ & 029 & 298 & ,524 \\
\hline Annetut kotitehtävät olen tehnyt sovitulla tavalla. &,- 002 &,- 019 & ,359 \\
\hline
\end{tabular}


Yläkoulun 12 tekijää muodostivat kolme faktoria, jotka nimettiin seuraavasti: Oppilaskeskeisyys (faktori 1), Monipuoliset opetusmenetelmät (faktori 2) ja Opettajajohtoisuus (faktori 3). Analyysista poistettiin kolme muuttujaa (Harjoitellaan päässälaskuja, Pidetään testejä ja kokeita, Kukin ratkaisee itselleen sopivan vaikeita tehtäviä), joiden lataus kaikille alkuperäisille faktoreille oli alle 0,30. Analyysin yhteydessä varmistettiin, että korrelaatiomatriisit soveltuvat faktorianalyysiin (Kaiserin testitulos 0,832 ja Barlettin sväärisyystesti: $\chi^{2}(66)=$ 7023,041; $p<0,001)$.

Lukion aikaisiin tekijöihin liittyvät faktorit ja niille latautuneet muuttujat näkyvät alla rotatoidussa faktorimatriisissa (taulukko 3).

Taulukko 3. Rotatoitu faktorimatriisi lukion aikaisista opetuksen pedagogisista ratkaisuista

\begin{tabular}{|c|c|c|c|c|}
\hline & 1 & 2 & 3 & 4 \\
\hline Opetus on sidottu käytännön tilanteisiin. & ,808 & ,061 & 087 &,- 128 \\
\hline Sovelletaan matematiikan taitoja arkielämän tilanteisiin. & ,479 & 129 & 196 &,- 136 \\
\hline Opiskeltavat asiat tulevat selväksi. & 050 & ,694 &,- 023 & 032 \\
\hline $\begin{array}{l}\text { Opettaja ottaa huomioon opetukseen liittyvät oppilaiden ideat ja } \\
\text { toiveet. }\end{array}$ &,- 031 & ,589 & ,073 &,- 090 \\
\hline Kukin ratkaisee itselleen sopivan vaikeita tehtäviä. &,- 145 & ,476 & 159 &,- 110 \\
\hline On yhteistä opetusta opettajan johdolla. &,- 046 & ,428 &,- 277 &,- 112 \\
\hline Annetut kotitehtävät olen tehnyt sovitulla tavalla. & 130 & ,381 &,- 022 & 071 \\
\hline Opiskelijat etenevät omassa tahdissaan. & 096 & ,331 & 163 &,- 029 \\
\hline Tehdään projektitöitä. & ,058 &,- 026 & ,748 & 058 \\
\hline Opitaan mittaamalla, rakentelemalla tai muulla tavoin tekemällä. & 139 &,- 001 & ,655 &,- 045 \\
\hline Opiskelijat käyttävät tietokonetta. & ,063 &,- 020 & ,598 & ,050 \\
\hline Opiskellaan ryhmissä tai pareittain. &,- 103 & 119 & ,433 &,- 176 \\
\hline Opiskelijat selittävät muille, miten ovat tehtävänsä ratkaisseet. & ,026 &,- 130 &,- 013 &,- 834 \\
\hline Pohditaan, onko tehtävän vastaus järkevä. & , 163 & 082 &,- 042 &,- 581 \\
\hline $\begin{array}{l}\text { Opiskelijat asettavat itselleen tavoitteita ja arvioivat } \\
\text { edistymistään. }\end{array}$ & 144 & ,086 & ,243 &,- 356 \\
\hline Opiskelijat neuvovat toisiaan. &,- 132 & ,236 & ,023 &,- 356 \\
\hline
\end{tabular}

Lukion 16 tekijästä muodostui neljä faktoria: Matematiikan yhteys käytäntöön (faktori 1), Oppijoiden tarpeiden huomioiminen (faktori 2), Monipuoliset opetusmenetelmät (faktori 3) ja Oppilaskeskeisyys (faktori 4). Analyysista poistetiin kaksi muuttujaa (Harjoitellaan päässälaskuja, Pidetään testejä ja kokeita), joiden lataus kaikille alkuperäisille faktoreille oli alle 0,30 . Kaiserin testin tulos $(0,835)$ ja Barlettin sväärisyystesti $\left(\chi^{2}(120)=7470,293 ; p<0,001\right)$ osoittivat, että korrelaatiomatriisi soveltuu faktorianalyysiin. 
Faktoreiden mukaan muodostettiin summamuuttujat, joiden reliabiliteetit näkyvät taulukoissa 4 ja 5 .

Taulukko 4. Summamuuttujat yläkoulun opetuksen pedagogisista ratkaisuista ja niiden reliabiliteetit

\begin{tabular}{lll}
\hline & Muuttujien määrä & Reliabiliteetti $(\alpha)$ \\
\hline 1 Oppilaskeskeisyys & 4 & 0,688 \\
$\begin{array}{l}\text { 2 Monipuoliset } \\
\text { opetusmenetelmät }\end{array}$ & 5 & 0,634 \\
3 Opettajajohtoisuus & 3 & 0,473 \\
\hline
\end{tabular}

Taulukko 5. Summamuuttujat lukion opetuksen pedagogisista ratkaisuista ja niiden reliabiliteetit

\begin{tabular}{lll}
\hline & Muuttujien määrä & Reliabiliteetti $(\alpha)$ \\
\hline $\begin{array}{l}1 \text { Matematiikan yhteys } \\
\text { käytäntöön }\end{array}$ & 2 & 0,728 \\
$\begin{array}{l}\text { 2 Oppijoiden tarpeiden } \\
\text { huomioiminen }\end{array}$ & 6 & 0,653 \\
$\begin{array}{l}\text { 3 Monipuoliset } \\
\text { opetusmenetelmät } \\
4 \text { Oppilaskeskeisyys }\end{array}$ & 4 & 0,708 \\
\hline
\end{tabular}

Koska yläkoulun opettajajohtoisuuteen liittyvän summamuuttujan reliabiliteettiarvo jäi heikoksi (alle o,6), jätettiin kyseinen summamuuttuja analyyseista pois ja tuloksia analysoidaan yksittäisten muuttujien osalta.

\section{Tulosten analysointi}

Tulosten kuvailussa käytetään perustunnuslukuja kuten frekvenssi- ja prosenttijakaumia sekä keskiarvo- ja keskihajontalukuja. Ryhmien välisiä eroja analysoidaan parametrisin testein kuten t-testillä ja yksisuuntaisella varianssianalyysilla. Efektikoon mittana käytetään Cohenin $f$-arvoa, joka ilmaisee varianssianalyysin yhteydessä havaittujen keskiarvojen välisen eron suuruuden (efektikoko on suuri, kun Cohenin $f>0,40$ ) (Cohen, 1988; Metsämuuronen, 2011).

Opetuksellisten tekijöiden yhteyttä asenteisiin analysoidaan monimuuttujamenetelmin. Analysoinnissa käytetään päätöspuuanalyysia (decision tree analysis, DTA) ja lineaarista regressioanalyysia. DTA-analyysilla tutkitaan laajaa aineistoa ja etsitään muuttujia, jotka erottelevat ja luokittelevat selitettävää muuttujaa. DTA-analyysin avulla saadaan tunnistettua ei-lineaarisia ilmiöitä. 
Analyysissa käytetään CHAID-algoritmia, joka etsii tilastollisesti samankaltaisia arvoja selittävän ja selitettävän muuttujan välillä. Algoritmi etsii ja luokittelee ryhmiä, joiden välinen ero on mahdollisimman suuri vertaamalla testien p-arvoja. Tässä tutkimuksessa p-arvoja etsitään F-testin avulla, kun selitettävät muuttujat ovat jatkuvia (Kass, 1980; Metsämuuronen, 2011).

Asiayhteyksien mallintamista ja asenteiden muutosta ennustavien tekijöiden analysoinnissa hyödynnetään lineaarista regressioanalyysia. Sen avulla muuttujien selitysosuudet saadaan paremmin näkyviin. Analyyseissa käytetään askeltavaa menettelyä, jossa yhtälöön lisätään riippumattomia muuttujia yksi kerrallaan ja samalla testataan, miten kunkin lisätyn muuttujan poistaminen vaikuttaa mallin selitysasteeseen (Metsämuuronen, 2011, s. 724). Lopulliseen malliin jää selitysvoimaltaan tilastollisesti merkitsevät muuttujat. Tabachnick \& Fidell (2007) kutsuvat menettelyä tilastolliseksi menettelyksi (statistical regression), koska selittävät muuttujat valitaan malliin vain tilastollisin perustein. Regressioanalyysin tulokset esitetään niin, että muuttujat ovat analyysin esittämässä järjestyksessä. Lineaarisen regressioanalyysin käytössä tulee ottaa huomioon, että muuttujien yhteydet eivät ole puhtaan lineaarisia. Havaittu vaikutus saattaa syntyä esimerkiksi muuttujan toisen ääripään voimakkaasta vaihtelusta (Metsämuuronen, 2009, s. 49).

DTA-analyysissa ja regressioanalyysissa analysoidaan erikseen yläkoulun ja lukion aikaiset opetukseen liittyvät tekijät. Ensin pyritään selvittämään, mitkä summamuuttujat selittävät parhaiten asenteen muutoksen vaihtelua ja sen jälkeen, mikä on yksittäisten tekijöiden selitysosuus vaihtelusta. Analyyseissa kontrolloidaan kansallisella kokeella mitattu osaamistaso ottamalla se analyyseihin mukaan. Jos sillä on tilastollisesti merkitsevä yhteys malliin, se esitetään tuloksissa. DTA-analyysi ja lineaarinen regressioanalyysi täydentävät toisiaan. DTA-analyysin avulla voidaan löytää tekijöitä, joita regressioanalyysi ei löydä, sillä DTA-analyysi tunnistaa myös muuttujien väliset epälineaariset ja -hierarkkiset yhteydet.

\section{Tulokset}

Raportoimme ensin, miten matematiikan parhaiden osaajien matematiikkaan liittyvät asenteet kehittyvät perusopetuksesta lukion loppuun ja millaisia eroja tyttöjen ja poikien välillä on minäkäsityksessä, matematiikasta pitämisessä ja matematiikan hyödyllisyyden kokemisessa tapahtuneissa muutoksissa. Sen jälkeen selvitämme, millaiset opetuksen pedagogiset ratkaisut yläkoulussa ja lukiossa selittävät tyttöjen ja poikien asenteissa tapahtuneita muutoksia. 


\section{Matematiikkaan liittyvien asenteiden kehitys perusopetuksesta lukion loppuun}

Kuviossa 1 esitetään, millä tasolla matematiikan parhaiden ja keskitason osaajien asenteet olivat lukion lopussa.

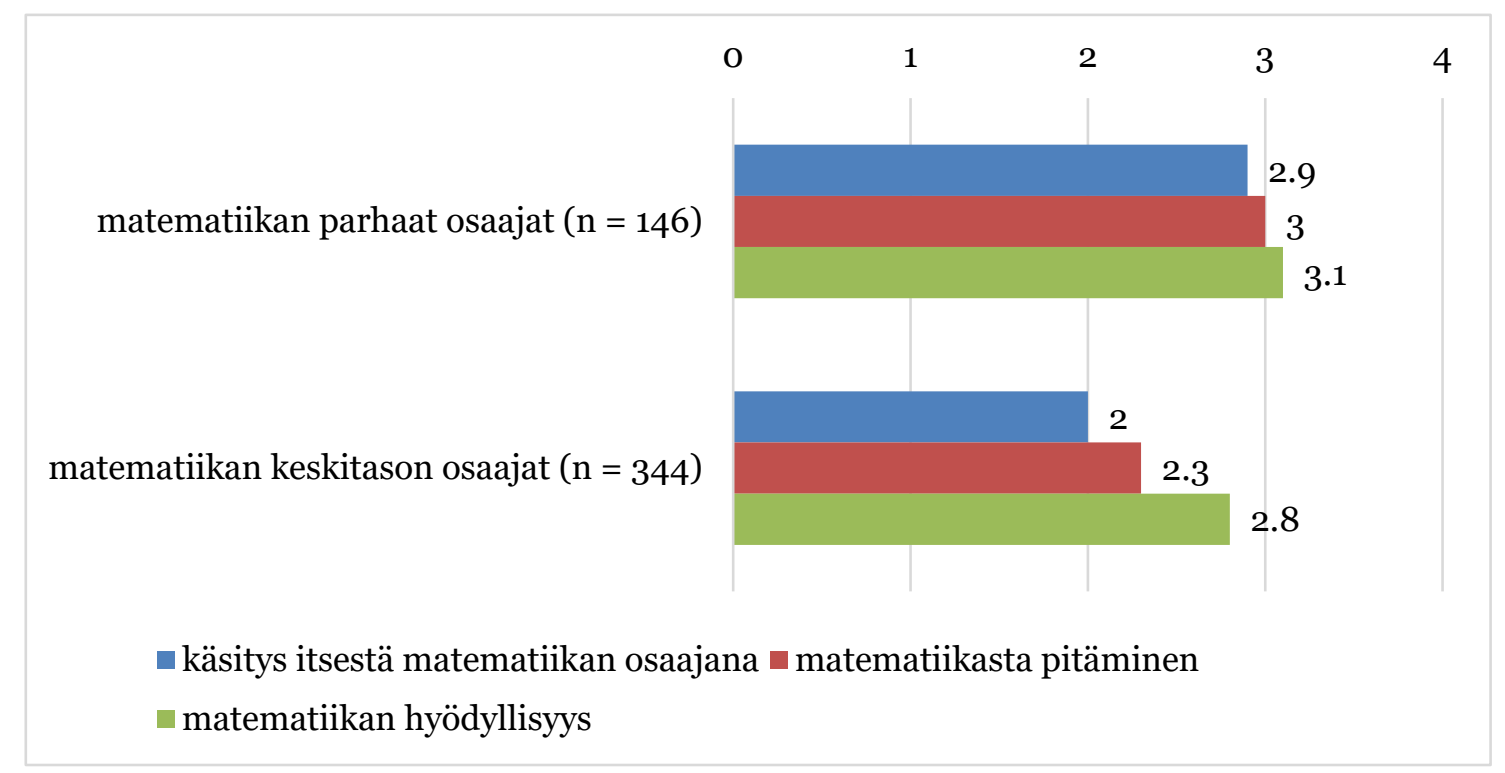

Kuvio 1. Matematiikan parhaiden ja keskitason osaajien matematiikka-asenteiden taso lukion lopussa

Yleisesti parhaiden osaajien asenteet olivat keskitason osaajien asenteita positiivisempia. Tämä näkyy erityisesti käsityksessä itsestä matematiikan osaajana ja matematiikasta pitämisessä. Molemmat ryhmät pitivät matematiikkaa lähes yhtä hyödyllisenä.

Kuviossa 2 esitetään, millaisia muutoksia parhaiden ja keskitason osaajien kokonaisasenteessa tapahtui peruskoulun ja lukion aikana. 


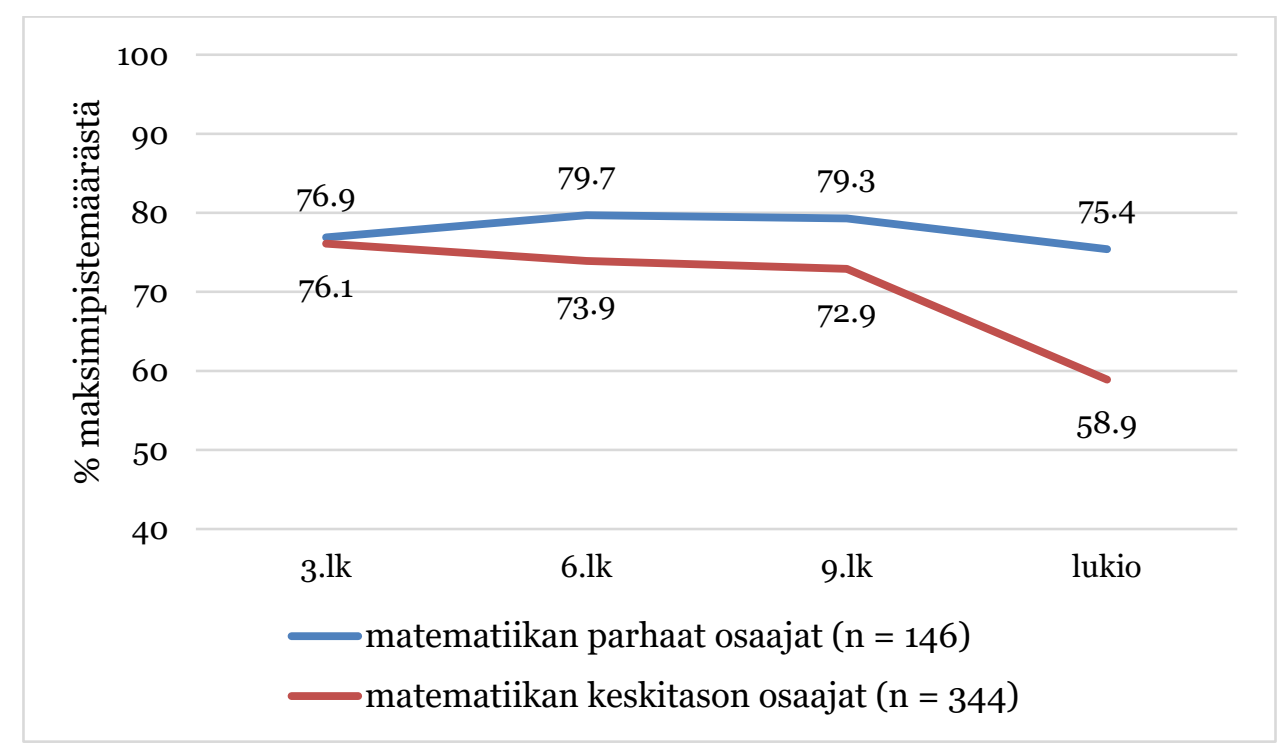

Kuvio 2. Matematiikan parhaiden ja keskitason osaajien kokonaisasenteessa tapahtuneet muutokset perusopetuksesta lukion loppuun

Matematiikan parhaiden ja keskitason osaajien kokonaisasenteen lähtötaso oli lähes sama kolmannen luokan alussa. Parhaiden osaajien asennoituminen pysyi melko vakaana koko perusopetuksen ja lukion ajan. Asennoituminen jopa hieman kasvoi perusopetuksen aikana. Sen sijaan keskitason osaajilla asennoituminen matematiikkaan alkoi heikentyä jo perusopetuksen aikana ja oli lukion lopussa lähes 20 prosenttiyksikköä heikompi kuin parhailla osaajilla.

Käsitys itsestä matematiikan osaajana

Kuviossa 3 kuvataan, millaisia keskiarvoihin perustuvia muutoksia matematiikassa parhaiten menestyneillä pojilla ja tytöillä tapahtui käsityksessä itsestä matematiikan osaajana perusopetuksesta lukion loppuun. Vertailukohtana ovat keskitason osaajat. 


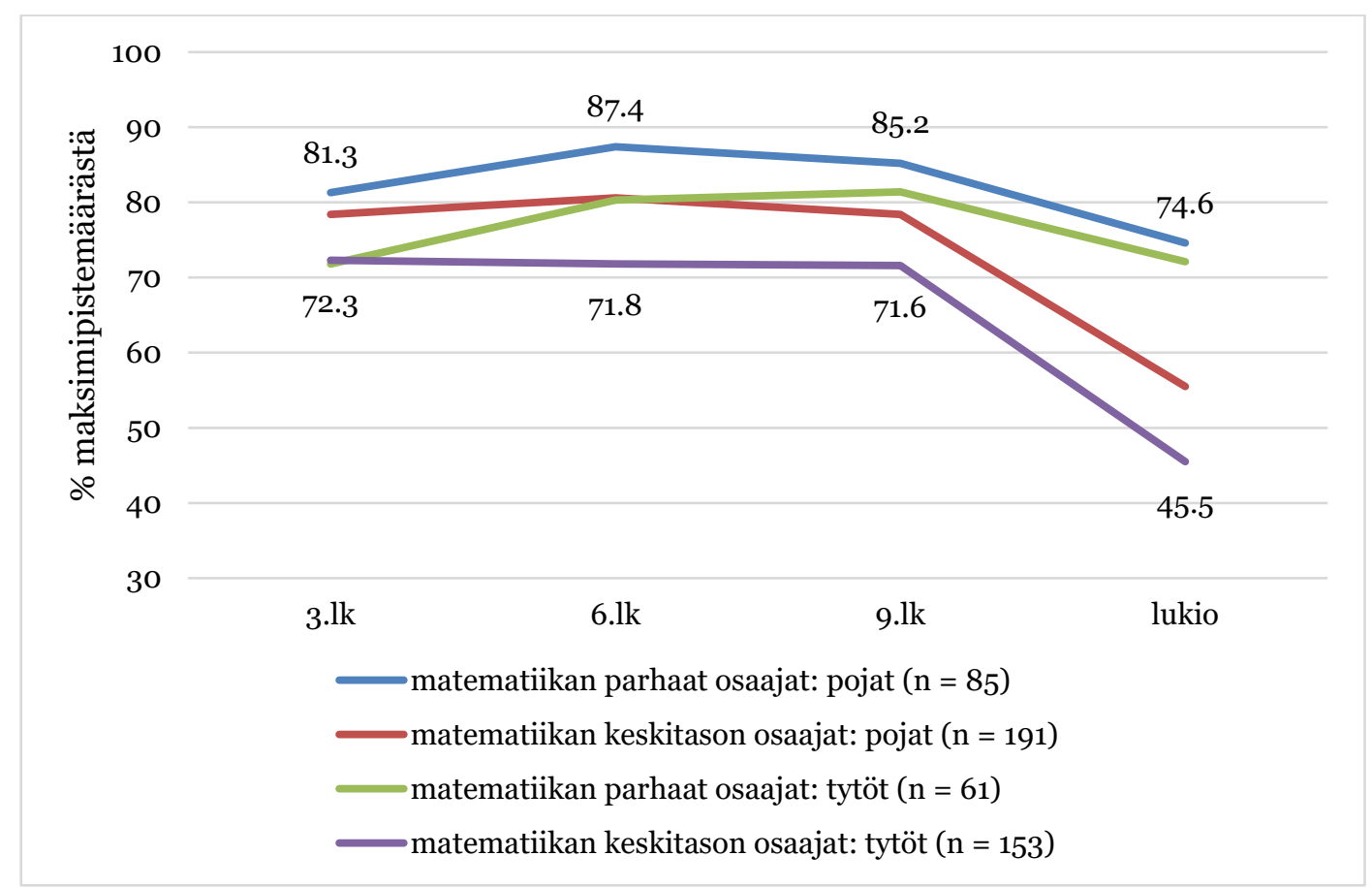

Kuvio 3. Minäkäsityksessä tapahtuneet muutokset perusopetuksesta lukion loppuun osaajaryhmien ja sukupuolen mukaan

Parhaiden poikien käsitys omasta osaamisesta pysyi koko ajan muita korkeammalla tasolla. Erot tyttöjen ja poikien minäkäsityksessä näkyvät selkeästi koko alakouluajan poikien hyväksi, mutta tytöt kuroivat poikien tasoa kiinni yläkoulun aikana ja sen jälkeen. Tyttöjen ja poikien minäkäsityksessä oli tilastollisesti merkitsevä ero vain kolmannella $(\mathrm{t}(133)=2,78 ; p=0,006)$ ja kuudennella luokalla $(\mathrm{t}(144)=3,02 ; p=0,003)$. Kolmannella luokalla varianssien ero oli 3,7 prosenttiyksikköä $\left(\mathrm{F}(101,59)=1,37, p=0,009, \eta^{2}=0,055\right.$, Cohenin $\left.f=0,23\right)$ ja kuudennella 4,2 prosenttiyksikköä $\left(\mathrm{F}(105,07)=12,05, p=0,005, \eta^{2}=0,060\right.$, Cohenin $f=0,24)$. Keskitason osaajilla sukupuolten välinen ero säilyi lukion loppuun asti. Kaikilla käsitys omasta osaamisesta heikkeni yläkoulusta lukioon siirtyessä, vaikka parhailla osaajilla heikentyminen ei ollut niin suurta kuin keskitason osaajilla.

Suurin muutos parhaiden osaajien minäkäsityksessä tapahtui siirtymävaiheessa yhdeksänneltä luokalta lukioon. Parhaiden tyttöjen ja poikien välisiä eroja minäkäsityksen muutoksessa havainnollistetaan kuvion 4 laatikko-janakuviolla (Box Plot). 


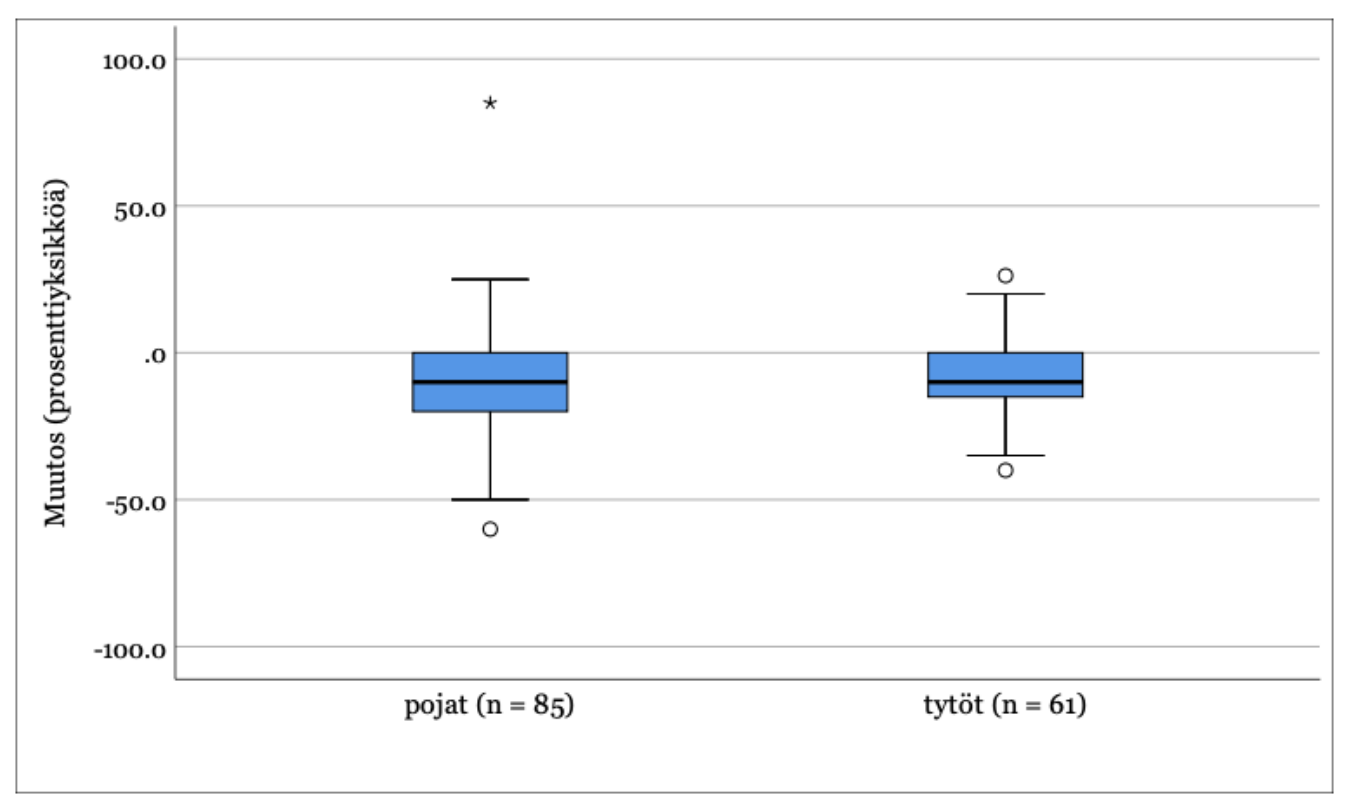

Kuvio 4. Matematiikan parhaiden osaajien minäkäsityksessä yhdeksänneltä luokalta lukion loppuun tapahtuneen muutoksen jakauma sukupuolittain

Minäkäsityksessä tapahtuneet muutokset jakautuvat samankaltaisesti pojilla ja tytöillä. Molemmissa ryhmissä minäkäsitys heikentyi mediaanilla mitattuna keskimäärin 10 prosenttiyksikköä. Pojilla muutoksen keskihajonta oli 19,1 prosenttiyksikköä ja tytöillä 13,1. Pojista neljänneksellä minäkäsitys heikkeni -20 prosenttiyksikköä tai enemmän ja tytöillä -15 prosenttiyksikköä tai enemmän. Neljänneksellä oppilaista minäkäsitys säilyi lukiossa vähintään samalla tasolla kuin se oli ollut yhdeksännellä luokalla tai se vahvistui lukion aikana.

Matematiikasta pitäminen

Matematiikasta pitämisessä tapahtuneet keksimääräiset muutokset esitetään kuviossa 5 . 


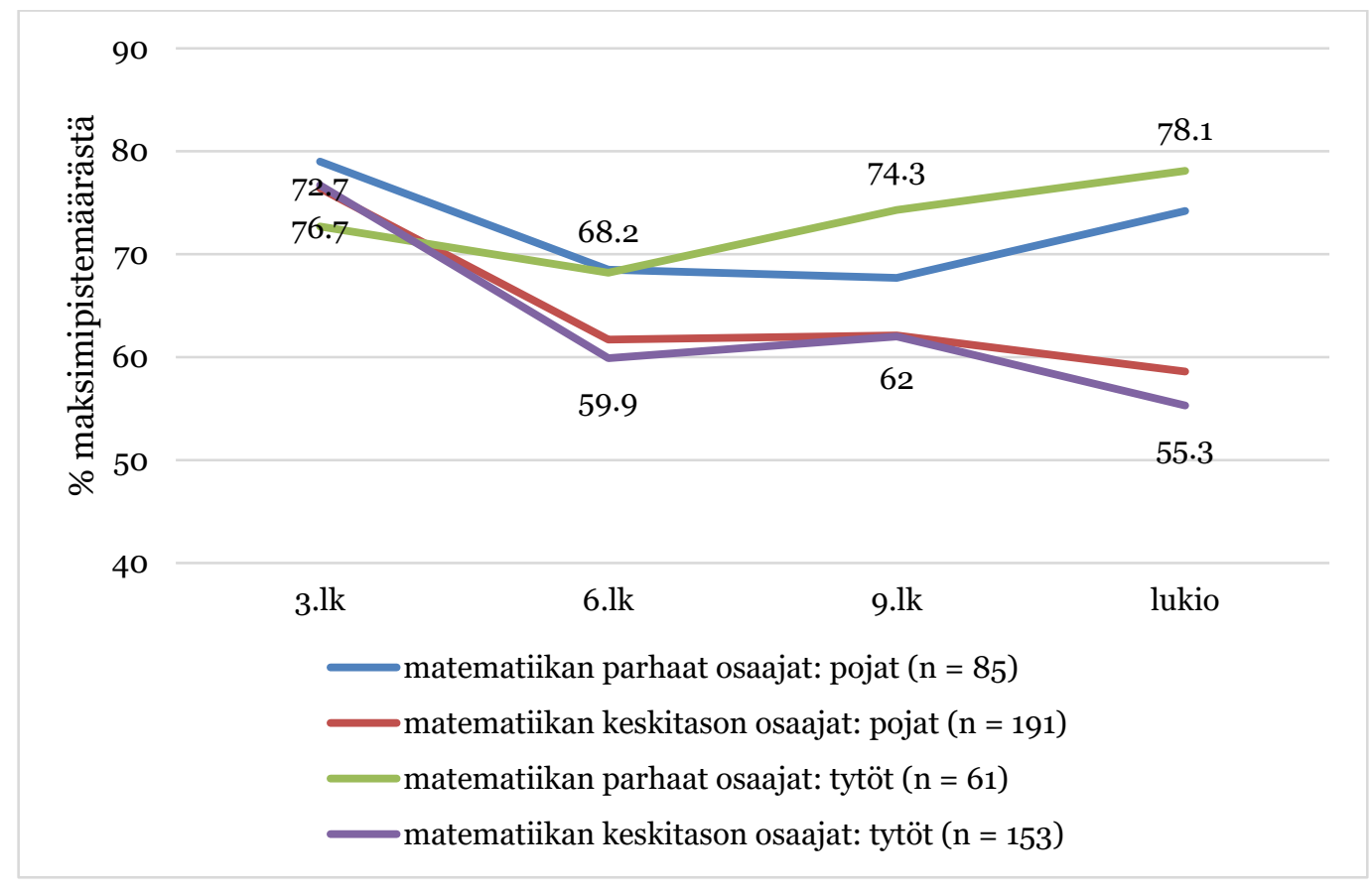

Kuvio 5. Matematiikasta pitämisen muutokset perusopetuksesta lukion loppuun osaajaryhmien ja sukupuolen mukaan

Keskitason osaajilla nähdään yleinen muutossuunta, jonka mukaan matematiikasta pitäminen heikkeni koko matkan perusopetuksesta lukion loppuun. Sen sijaan parhailla osaajilla matematiikasta pitäminen vahvistui entisestään lukion aikana. On huomioitavaa, että parhaiden tyttöjen muutossuunta erottuu muista tytöistä sekä parhaista pojista. Parhaat tytöt pitivät matematiikasta kaikkein vähiten kolmannella luokalla. Matematiikasta pitäminen heikkeni tytöillä hieman vielä alakoulun aikana kunnes se lähti jyrkkään kasvuun yläkoulun aikana. Parhaat tytöt pitivät lukion lopussa matematiikasta kaikkein eniten ja saavuttivat parhaiden poikien kolmannen luokan lähtötason. Parhaiden tyttöjen ja poikien väliset erot matematiikasta pitämisessä eivät olleet millään luokka-asteella tilastollisesti merkitseviä.

Matematiikasta pitämisen muutoksissa yhdeksänneltä luokalta lukion kolmannelle vuodelle oli suurta vaihtelua (kuvio 6). Erityisesti pojilla muutoksen vaihteluväli oli tyttöjä suurempi. 


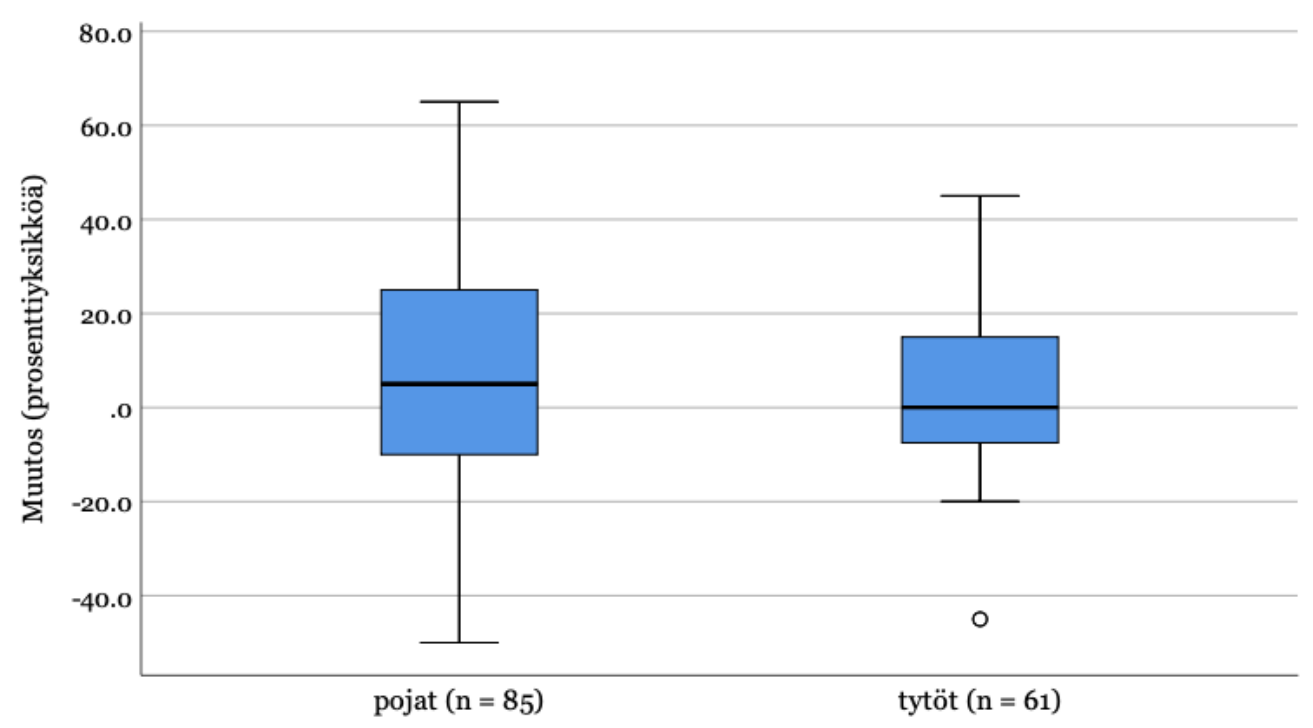

Kuvio 6. Matematiikan parhaiden osaajien matematiikasta pitämisessä yhdeksänneltä luokalta lukion loppuun tapahtuneen muutoksen jakauma sukupuolittain

Muutoksen keskihajonta oli pojilla 24,1 prosenttiyksikköä ja tytöillä 18,8. Mediaanilla mitattuna matematiikasta pitäminen pysyi molemmissa ryhmissä samalla tasolla lukion lopussa kuin yhdeksännellä luokalla. Sekä tytöistä että pojista neljänneksellä matematiikasta pitäminen laski vähintään 10 prosenttiyksikköä. Toisaalta matematiikasta pitäminen kasvoi neljänneksellä pojista vähintään 25 prosenttiyksikköä ja neljänneksellä tytöistä vähintään 15 prosenttiyksikköä.

Matematiikan hyödyllisyys

Opiskelijoiden käsitys matematiikan hyödyllisyydestä pääsääntöisesti laski kuudennelta luokalta lukioon ja erityisesti lukiossa (kuvio 7). 


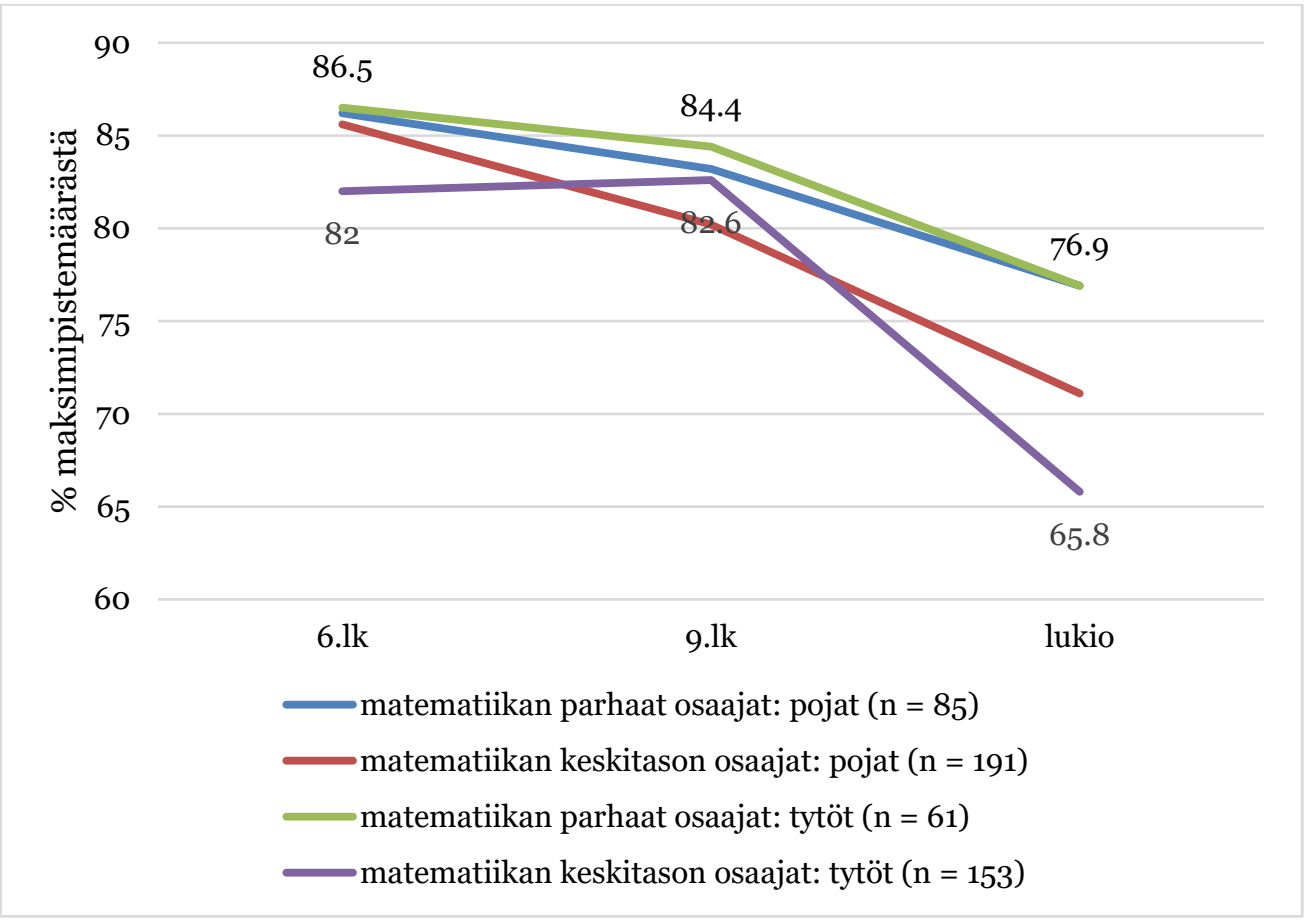

Kuvio 7. Matematiikan hyödyllisyyden kokemisen muutokset perusopetuksesta lukion loppuun osaajaryhmien ja sukupuolen mukaan

Parhaiden osaajien kokema matematiikan hyödyllisyys pysyi koko ajan keskitason osaajia korkeammalla tasolla eikä poikien ja tyttöjen välillä ollut havaittavissa juurikaan eroja keskiarvojen suhteen eivätkä erot olleet tilastollisesti merkitseviä. Osaamiseltaan keskitasoa olevien poikien kokema hyödyllisyys oli kuudennella luokalla lähes yhtä korkealla tasolla kuin osaamiseltaan parhaiden poikien kanssa, mutta asennoituminen lähti jyrkkään laskuun yläkoulun aikana ja heikkeni aina lukion loppuun asti. Osaamiseltaan keskitasoa olevien tyttöjen kokemus matematiikan hyödyllisyydestä oli muita hieman alhaisempi kuudennella luokalla, mutta se kehittyi yläkoulun aikana osaamiseltaan parhaiden tyttöjen tasolle. Lukion aikana koettu hyödyllisyys kuitenkin heikkeni lähes 20 prosenttiyksikköä.

Parhaiden osaajien kokemus matematiikan hyödyllisyydestä muuttui voimakkaimmin yhdeksänneltä luokalta lukion loppuun. Parhaiden tyttöjen ja poikien käsitykset hyödyllisyydestä kehittyivät jälleen erisuuntaisesti (kuvio 8). Tytöillä käsitys hyödyllisyydestä keskimäärin laski lukioaikana, kun taas pojilla se pysyi keskimäärin ennallaan. Poikien muutoksessa oli suurempi hajonta kuin tytöillä. 


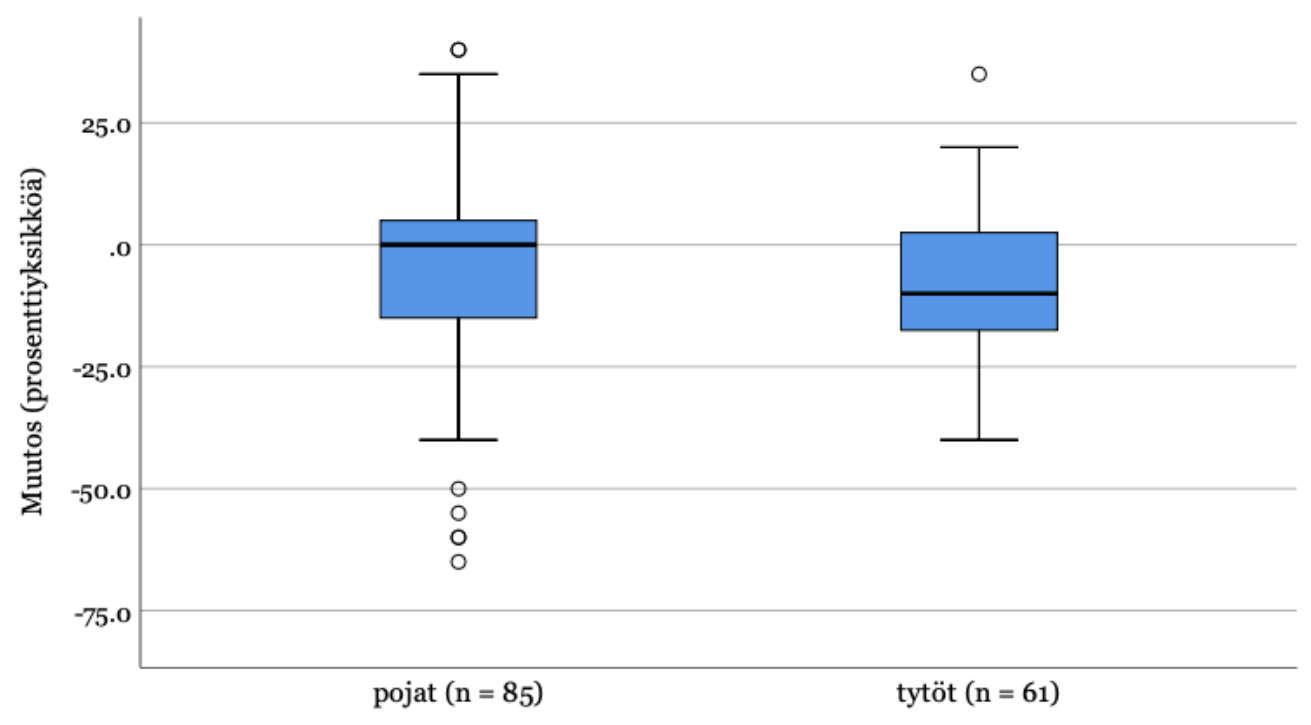

Kuvio 8. Matematiikan parhaiden osaajien matematiikan hyödyllisyyden kokemisessa yhdeksänneltä luokalta lukion loppuun tapahtuneen muutoksen jakauma sukupuolittain

Pojilla muutoksen keskihajonta oli 21,4 prosenttiyksikköä ja tytöillä 15,5 prosenttiyksikköä. Pojilla kokemus matematiikan hyödyllisyydestä mediaanilla mitattuna pysyi lukiossa keskimäärin samalla tasolla kuin yhdeksännellä luokalla ja tytöillä koettu hyödyllisyys heikkeni keskimäärin 10 prosenttiyksikköä. Pojista vähintään neljänneksellä koettu hyödyllisyys heikkeni 15 prosenttiyksikköä tai enemmän ja tytöistä neljänneksellä 20 prosenttiyksikköä tai enemmän. Sekä pojista että tytöistä neljänneksellä matematiikan hyödyllisyyden kokeminen kasvoi 5 prosenttiyksikköä tai enemmän. Pojilla tapahtui tyttöjä enemmän keskiarvoa heikentäviä muutoksia toisessa ääripäässä.

\section{Opetustekijöiden yhteys parhaiden osaajien asennemuutoksiin yhdeksänneltä luokalta lukion loppuun}

Seuraavaksi selvitetään, miten opetuksen pedagogiset ratkaisut opiskelijoiden arvioimana yläkoulussa ja lukiossa selittävät matematiikan parhaiden osaajien asenteissa tapahtuneita muutoksia yhdeksänneltä luokalta lukion loppuun. Analyysit tehdään tytöille ja pojille erikseen ja pyritään selvittämään, millaisia eroja löytyy sukupuolten välillä. 
Käsitys itsestä matematiikan osaajana

Parhaiden tyttöjen minäkäsityksen muutosta selittävät DTA-analyysin tulokset esitetään taulukossa 6. Yläkoulun aikaisista tekijöistä ei löytynyt analyysissa muutoksen vaihtelua selittävää muuttujaryhmää tai yksittäistä tekijää vaan tulokset koskevat lukion aikaisia pedagogisia ratkaisuja.

Taulukko 6. Tyttöjen minäkäsityksen muutosta yhdeksänneltä luokalta lukion loppuun erottelevat tekijät DTA-analyysin mukaan (tähdellä * merkitty muuttujien välinen yhteisvaikutus)

\begin{tabular}{llll}
\hline & $\begin{array}{l}\text { prosenttiosuus } \\
\text { parhaista tytöistä } \\
(\mathbf{n = 5 5 )}\end{array}$ & $\begin{array}{l}\text { toistuvuus } \\
\text { (asteikolla 1-5) }\end{array}$ & $\begin{array}{l}\text { minäkäsityksen } \\
\text { muutos } \\
\text { (prosenttiyksikköä) }\end{array}$ \\
\hline $\begin{array}{l}\text { Opetuksen pedagogiset ratkaisut } \\
\text { lukiossa }\end{array}$ & & \\
\hline Pidetään testejä ja kokeita. & 10,9 & $>4,0$ & $+6,0$ \\
& 36,4 & $(3,0,4,0]$ & $-15,3$ \\
& 52,7 & $\leq 3,0 *$ & $-8,3$ \\
\hline *Opiskelijat asettavat & 41,8 & $>1,0$ & $-6,0$ \\
itselleen tavoitteita ja & 10,9 & 1,0 & $-17,3$ \\
arvioivat edistymistään. & & & \\
\hline
\end{tabular}

Lukio-opetuksen yksittäisistä tekijöistä minäkäsityksen muutosta erotteli parhaiten se, että matematiikan tunneilla pidetään testejä ja kokeita $(\mathrm{F}(2,52)=7,886$; $p=0,022$ ). Tytöillä, jotka arvioivat matematiikan testejä ja kokeita lukiossa pidetyn enemmän kuin usein, käsitys omasta osaamisesta kasvoi lukion aikana 6 prosenttiyksikköä. Jos kokeita pidettiin joskus tai tätä harvemmin, tyttöjen minäkäsitys heikkeni noin 8 prosenttiyksikköä. Jos kuitenkin tytöt arvioivat toteuttaneensa itsearviointia useammin kuin harvoin, minäkäsitys heikkeni enää 6 prosenttiyksikköä $(\mathrm{F}(1,27)=7,215 ; p=0,037)$. Jos osaamista ei arvioitu millään tavalla, tyttöjen käsitys omasta osaamisesta heikkeni noin 17 prosenttiyksikköä.

Taulukossa 7 esitetään tyttöjen minäkäsityksen muutosta selittävän askeltavan regressioanalyysin tulokset, joissa löytyi vain yksi selittävä muuttuja yläkoulun osalta. 
Taulukko 7. Tyttöjen minäkäsityksen muutosta yhdeksänneltä luokalta lukion loppuun selittävät tekijät askeltavan regressioanalyysin mukaan

\begin{tabular}{|c|c|c|c|c|}
\hline & \multicolumn{4}{|c|}{ Muutoksen vaihtelu minäkäsityksessä, tytöt } \\
\hline & $B$ & $S E$ & beta & $p$ \\
\hline \multicolumn{5}{|l|}{$\begin{array}{l}\text { Malli } 1 \text { - Opetuksen pedagogiset } \\
\text { ratkaisut yläkoulussa }\end{array}$} \\
\hline Vakio & 15,368 & 10,417 & & 0,146 \\
\hline $\begin{array}{l}\text { Annetut kotitehtävät olen tehnyt } \\
\text { sovitulla tavalla. }\end{array}$ & $-5,386$ & 2,255 & $-0,314$ & 0,021 \\
\hline & \multicolumn{4}{|c|}{$\mathrm{F}(1,52)=5,702 ; p=0,021 ; R=0,314 ; R^{2}=0,099$} \\
\hline
\end{tabular}

Tytöillä minäkäsityksen vaihtelua selitti parhaiten yksittäinen tekijä, jonka mukaan oppilas tekee annetut kotitehtävät sovitulla tavalla. Vaikutus muutokseen on negatiivinen eli minäkäsitys heikentyi lukiossa. Tällaisella oppilaalla minäkäsityksen lähtötaso oli korkea yhdeksännellä luokalla.

Poikien minäkäsityksen muutosta selittäviä tekijöitä etsivän DTA-analyysin tulokset näkyvät taulukossa 8. Yläkoulun aikaisista tekijöistä ei löytynyt muutoksen vaihtelua selittävää tekijää, joten tulokset koskevat vain pedagogisia ratkaisuja lukiossa.

Taulukko 8. Poikien minäkäsityksen muutosta yhdeksänneltä luokalta lukion loppuun erottelevat tekijät DTA-analyysin mukaan (tähdellä * merkitty muuttujien välinen yhteisvaikutus)

\begin{tabular}{llll}
\hline & $\begin{array}{l}\text { prosenttiosuus } \\
\text { parhaista pojista } \\
(\mathbf{n}=\mathbf{7 4 )}\end{array}$ & $\begin{array}{l}\text { minäkäsityksen } \\
\text { toistuvuus } \\
\text { (asteikolla 1-5) }\end{array}$ & $\begin{array}{l}\text { muutos } \\
\text { (prosenttiyksikköä) }\end{array}$ \\
\hline $\begin{array}{l}\text { Opetuksen pedagogiset ratkaisut } \\
\text { lukiossa }\end{array}$ & & \\
\hline Opiskelijat selittävät muille, miten & 13,5 & $>4,0$ & $+7,5$ \\
Ovat tehtävänsä ratkaisseet. & 86,5 & $\leq 4,0 *$ & $-13,8$ \\
\hline *Opiskellaan ryhmissä tai & 10,8 & $>3,0$ & $-21,9$ \\
pareittain. & 60,8 & $(1,0 ; 3,0]$ & $-10,2$ \\
& 14,9 & 1,0 & $-22,3$ \\
\hline
\end{tabular}

Yksittäisistä lukioon liittyvistä tekijöistä poikien käsitystä omasta osaamisesta vahvisti parhaiten se, että matematiikan tunneilla opiskelijat selittävät muille, miten ovat tehtävänsä ratkaisseet $(\mathrm{F}(1,72)=12,353 ; p=0,003)$. Pojista niillä, jotka arvioivat selittäneensä muille tehtäviensä ratkaisuja enemmän kuin usein, arvio omasta osaamisesta kasvoi lähes 8 prosenttiyksikköä. Ne, jotka arvioivat ratkaisujen selittämistä muille tapahtuneen enintään usein, minäkäsitys heikkeni noin 14 prosenttiyksikköä. Se, että opiskelijat eivät selittäneet omia ratkaisujaan toisille kovin 
usein, oli poikien minäkäsitykselle haitallisinta silloin, kun opiskelijat eivät opiskelleet pareittain tai ryhmissä lainkaan tai pari- tai ryhmätyöskentelyä oli usein.

Taulukossa 9 esitetään askeltavan regressioanalyysin tulokset poikien minäkäsityksen muutoksen selittämisestä. Tilastollisesti merkitsevä muuttuja löytyi vain lukio-opetukseen liittyvistä yksittäisistä tekijöistä.

Taulukko 9. Poikien minäkäsityksen muutosta yhdeksänneltä luokalta lukion loppuun selittävät tekijät askeltavan regressioanalyysin mukaan

\begin{tabular}{llcc}
\hline & \multicolumn{3}{c}{ Muutoksen vaihtelu minäkäsityksessä, pojat } \\
\cline { 2 - 4 } & $B$ & $S E$ & beta \\
\hline $\begin{array}{l}\text { Malli 1 - Opetuksen pedagogiset } \\
\text { ratkaisut lukiossa }\end{array}$ & & & \\
\hline Vakio & $-26,720$ & 7,312 & 0,001 \\
\hline $\begin{array}{l}\text { Opiskelijat selittävät muille, miten ovat } \\
\text { tehtävänsä ratkaisseet. }\end{array}$ & 4,866 & 2,050 & 0,279 \\
\hline
\end{tabular}

Tulos vahvistaa DTA-analyysin tulosta, jonka mukaan parhaiden poikien minäkäsitys vahvistui, kun he selittivät muille, miten ovat tehtävänsä ratkaisseet. Yhteenvetona voidaan todeta, että parhailla tytöillä käsitystä omasta osaamisesta näyttäisi vahvistaneen se, että he saivat osaamisestaan palautetta (kokeet ja itsearviointi) ja opiskelu tapahtui opettajan antamien tehtävien mukaisesti. Parhaiden poikien minäkäsitys vahvistui, kun he saivat osoittaa osaamistaan muille.

\section{Matematiikasta pitäminen}

Tyttöjen matematiikasta pitämisessä tapahtuneita muutoksia selittävät tekijät DTAanalyysilla mitattuna näkyvät taulukossa 10. Selittäviä tekijöitä löytyi sekä yläkoulun että lukion pedagogisista ratkaisuista. 
Taulukko 10. Tyttöjen matematiikasta pitämisessä tapahtuneita muutoksia yhdeksänneltä luokalta lukion loppuun erottelevat tekijät DTA-analyysin mukaan (tähdillä * ja ** merkitty muuttujien väliset yhteisvaikutukset)

\begin{tabular}{|c|c|c|c|}
\hline & $\begin{array}{l}\text { prosenttiosuus } \\
\text { parhaista tytöistä } \\
(n=55)\end{array}$ & $\begin{array}{l}\text { toistuvuus } \\
\text { (asteikolla 1-5) }\end{array}$ & $\begin{array}{l}\text { muutos } \\
\text { matematiikasta } \\
\text { pitämisessä } \\
\text { (prosenttiyksikköä) }\end{array}$ \\
\hline \multicolumn{4}{|l|}{$\begin{array}{l}\text { Opetuksen pedagogiset ratkaisut } \\
\text { yläkoulussa }\end{array}$} \\
\hline \multirow{4}{*}{$\begin{array}{l}\text { Monipuoliset opetusmenetelmät } \\
\text { (faktori 2) }\end{array}$} & 32,7 & $>2,0$ & $-5,6$ \\
\hline & 12,7 & $(1,8 ; 2,0]$ & 16,5 \\
\hline & 30,9 & $(1,4 ; 1,8]$ & $-2,4$ \\
\hline & 23,6 & $\leq 1,4$ & 17,1 \\
\hline \multirow{2}{*}{$\begin{array}{l}\text { Sovelletaan matematiikan taitoja } \\
\text { arkielämän tilanteisiin. }\end{array}$} & 50,9 & $>2,0 *$ & $-3,0$ \\
\hline & 49,1 & $\leq 2,0 * *$ & 10,5 \\
\hline \multirow{2}{*}{$\begin{array}{l}\text { Annetut kotitehtävät olen } \\
\text { tehnyt sovitulla tavalla.* }\end{array}$} & 34,5 & $>4,0$ & $-8,4$ \\
\hline & 16,4 & $\leq 4,0$ & 8,3 \\
\hline \multirow{2}{*}{$\begin{array}{l}\text { Opitaan mittaamalla, } \\
\text { rakentelemalla tai muulla } \\
\text { tavoin tekemällä.** }\end{array}$} & 30,9 & $>1,0$ & 2,1 \\
\hline & 18,2 & 1,0 & 24,8 \\
\hline \multicolumn{4}{|l|}{$\begin{array}{l}\text { Opetuksen pedagogiset ratkaisut } \\
\text { lukiossa }\end{array}$} \\
\hline \multirow{2}{*}{$\begin{array}{l}\text { Monipuoliset opetusmenetelmät } \\
\text { (faktori 3) }\end{array}$} & 63,6 & $>1,3$ & $-1,5$ \\
\hline & 36,4 & $\leq 1,3$ & 12,5 \\
\hline \multirow[t]{2}{*}{ Tehdään projektitöitä. } & 21,8 & $>1,0^{*}$ & $-7,5$ \\
\hline & 78,2 & 1,0 & 6,7 \\
\hline \multirow{2}{*}{$\begin{array}{l}\text { Sovelletaan matematiikan } \\
\text { taitoja arkielämän } \\
\text { tilanteisiin.* }\end{array}$} & 9,1 & $>2,0$ & 3,0 \\
\hline & 12,7 & $\leq 2,0$ & $-15,0$ \\
\hline
\end{tabular}

Monipuolisten opetusmenetelmien käyttö oli selittävänä muuttujana sekä yläkoulussa että lukiossa. Tällaisten opetusmenetelmien runsas käyttö näyttäisi kuitenkin selittäneen parhaiden tyttöjen matematiikasta pitämistä eri tavalla yläkoulussa ja lukiossa. Yläkoulussa pedagogisten ratkaisujen toistuvuus selitti asenteessa tapahtuneen muutoksen lähtötasoa. Parhaiden tyttöjen matematiikasta pitäminen parani keskimäärin 10 prosenttiyksikköä (muutosten keskiarvo, kun toistuvuus $\leq 2,0$ ), jos monipuolisia opetusmenetelmiä toteutettiin yläkoulussa harvoin tai ei lainkaan ja heikkeni lähes 6 prosenttiyksikköä, jos näitä opetusmenetelmiä toteutettiin ainakin joskus $(\mathrm{F}(3,51)=7,121 ; p=0,015)$. Jos yläkoulussa toteutettiin monipuolisia opetusmenetelmiä keskimääräistä enemmän, parhaiden tyttöjen matematiikasta pitäminen oli yläkoulussa korkealla tasolla ja heikkeni tästä lukion aikana. Jos näitä opetusmenetelmiä toteutettiin keskimääräistä 
vähemmän, matematiikasta pitämisen lähtötaso oli alhaisempi ja matematiikasta pitäminen parani lukion aikana.

Yläkoulun yksittäisistä tekijöistä muutoksen vaihtelua erotteli se, kuinka usein matematiikan taitoja sovelletaan arkielämän tilanteisiin $(\mathrm{F}(1,53)=8,000 ; p=$ 0,020). Tytöistä puolet arvioi, että soveltamista tapahtui useammin kuin harvoin ja heillä matematiikasta pitäminen heikkeni 3 prosenttiyksikköä. Toisin sanoen tytöt pitivät matematiikasta enemmän yläkoulussa kuin lukiossa, jos taitoja sovellettiin yläkoulussa arkielämän tilanteisiin. Lisäksi, jos oppilas arvioi tehneensä annetut kotitehtävät sovitulla tavalla enemmän kuin usein, heikkeni matematiikasta pitäminen noin 8 prosenttiyksikköä $(\mathrm{F}(1,26)=7,072 ; p=0,026)$. Parhaiden tyttöjen matematiikasta pitäminen oli yläkoulussa todennäköisesti sitä korkeammalla tasolla, mitä enemmän taitoja sovellettiin arkielämän tilanteisiin ja mitä useammin oppilaat tekivät kotitehtäviä. Jos matematiikan taitoja sovellettiin harvoin tai ei lainkaan, tyttöjen matematiikasta pitäminen parani lukion aikana noin 11 prosenttiyksikköä. Jos tähän kuitenkin yhdistyi mittaamalla, rakentelemalla tai muulla tavoin tekemällä oppimista vähintään harvoin, matematiikasta pitäminen kasvoi enää noin 2 prosenttiyksikköä. Jos tekemällä oppimista ei ollut lainkaan, matematiikasta pitäminen kasvoi jopa noin 25 prosenttiyksikköä $(\mathrm{F}(1,25)=15,196 ; p=0,001)$. Tekemällä oppiminen yläkoulussa paransi parhaiden tyttöjen matematiikasta pitämisen lähtötasoa.

Lukiossa monipuolisten opetusmenetelmien toistuva käyttö näyttäisi heikentäneen parhaiden tyttöjen matematiikasta pitämistä $(\mathrm{F}(1,53)=7,963 ; p=$ o,034). Yksittäisistä tekijöistä se, että tunneilla tehdään projektitöitä enemmän kuin harvoin, heikensi tyttöjen matematiikasta pitämistä lähes 8 prosenttiyksikköä $(\mathrm{F}(1,53)=5,815 ; p=0,039)$. Jos projektitöiden tekemiseen yhdistyi matematiikan taitojen soveltaminen arkielämän tilanteisiin, matematiikasta pitämisen muutos olikin positiivinen $(+3,0$ prosenttiyksikköä), mutta heikkeni entisestään (muutos 15,o prosenttiyksikköä), jos soveltamista oli harvoin tai ei lainkaan $(\mathrm{F}(1,10)=6,176$; $p=0,032)$. Eniten matematiikasta pitäminen kasvoi, jos projektitöitä ei toteutettu lukiossa opiskelijoiden arvioimana lainkaan (muutos $+6,7$ prosenttiyksikköä).

Taulukossa 11 on askeltavan regressioanalyysin tulokset tyttöjen matematiikasta pitämisessä tapahtuneiden muutosten selityksiin. 
Taulukko 11. Tyttöjen matematiikasta pitämisessä tapahtuneita muutoksia yhdeksänneltä luokalta lukion loppuun selittävät tekijät askeltavan regressioanalyysin mukaan

Muutoksen vaihtelu matematiikasta pitämisessä, tytöt

\begin{tabular}{|c|c|c|c|c|}
\hline & $B$ & $S E$ & beta & $p$ \\
\hline \multicolumn{5}{|l|}{$\begin{array}{l}\text { Malli } 1 \text { - Opetuksen pedagogiset } \\
\text { ratkaisut yläkoulussa }\end{array}$} \\
\hline Vakio & 25,634 & 9,453 & & 0,009 \\
\hline \multirow[t]{2}{*}{$\begin{array}{l}\text { Monipuoliset opetusmenetelmät } \\
\text { (faktori 2) }\end{array}$} & $-11,646$ & 4,826 & $-0,315$ & 0,019 \\
\hline & \multicolumn{4}{|c|}{$\mathrm{F}(1,53)=5,823 ; p=0,019 ; R=0,315 ; R^{2}=0,099$} \\
\hline Vakio & 20,911 & 6,994 & & 0,004 \\
\hline \multirow[t]{2}{*}{$\begin{array}{l}\text { Sovelletaan matematiikan taitoja } \\
\text { arkielämän tilanteisiin. }\end{array}$} & $-6,595$ & 2,548 & $-0,338$ & 0,012 \\
\hline & \multicolumn{4}{|c|}{$\mathrm{F}(1,52)=6,701 ; p=0,012 ; R=0,338 ; R^{2}=0,114$} \\
\hline \multicolumn{5}{|l|}{$\begin{array}{l}\text { Malli } 2 \text { - Opetuksen pedagogiset } \\
\text { ratkaisut lukiossa }\end{array}$} \\
\hline Vakio & 26,121 & 9,036 & & 0,006 \\
\hline \multirow[t]{2}{*}{$\begin{array}{l}\text { Monipuoliset opetusmenetelmät } \\
\text { (faktori 3) }\end{array}$} & $-13,884$ & 5,366 & $-0,335$ & 0,012 \\
\hline & \multicolumn{4}{|c|}{$\mathrm{F}(1,53)=6,694 ; p=0,012 ; R=0,335 ; R^{2}=0,112$} \\
\hline Vakio & 19,149 & 6,945 & & 0,008 \\
\hline $\begin{array}{l}\text { Matematiikan tunneilla tehdään } \\
\text { projektitöitä. }\end{array}$ & $-12,819$ & 5,193 & $-0,330$ & 0,017 \\
\hline
\end{tabular}

Tulokset vahvistavat DTA-analyysin tuloksia. Parhaiden tyttöjen matematiikasta pitäminen laski todennäköisesti lukion aikana sitä enemmän, mitä useammin yläkoulun opetuksessa toteutettiin monipuolisia opetusmenetelmiä ja asenteen lähtötaso oli korkealla. Lukiossa monipuolisten opetusmenetelmien toistuvuus sen sijaan heikensi parhaiden tyttöjen matematiikasta pitämistä.

Poikien matematiikasta pitämisessä tapahtuneita muutoksia selittävät DTAanalyysin tulokset ovat taulukossa 12. Yläkoulun tekijöistä ei löytynyt selittäviä tekijöitä, joten tulokset on esitetty vain lukioon liittyvien tekijöiden osalta. 
Taulukko 12. Poikien matematiikasta pitämisessä tapahtuneita muutoksia yhdeksänneltä luokalta lukion loppuun erottelevat tekijät DTA-analyysin mukaan

\begin{tabular}{llll}
\hline & $\begin{array}{l}\text { prosenttiosuus } \\
\text { parhaista pojista } \\
(\mathbf{n}=\mathbf{7 4})\end{array}$ & $\begin{array}{l}\text { toistuvuus } \\
\text { (asteikolla 1-5) }\end{array}$ & $\begin{array}{l}\text { muutos } \\
\text { matematiikasta } \\
\text { pitämisessä } \\
\text { (prosenttiyksikköä) }\end{array}$ \\
\hline $\begin{array}{l}\text { Opetuksen pedagogiset ratkaisut } \\
\text { lukiossa }\end{array}$ & & \\
\hline $\begin{array}{l}\text { Monipuoliset opetusmenetelmät } \\
\text { (faktori 3) }\end{array}$ & 58,1 & $>1,5$ & $+0,5$ \\
\hline $\begin{array}{l}\text { Opiskeltavat asiat tulevat } \\
\text { selväksi. }\end{array}$ & 41,9 & $\leq 1,5$ & $+16,0$ \\
\hline
\end{tabular}

Monipuolisiin opetusmenetelmiin liittyvät tekijät erottelivat parhaiten myös poikien matematiikasta pitämisessä tapahtuneita muutoksia $(\mathrm{F}(1,72)=8,253 ; p=$ o,032). Parhaista pojista noin 40 prosentilla matematiikasta pitäminen lisääntyi 16 prosenttiyksikköä, kun lukiossa toteutettiin harvoin tai ei lainkaan monipuolisia opetusmenetelmiä. Jos monipuolisia opetusmenetelmiä toteutettiin harvoin tai tätä useammin, parhaiden poikien matematiikasta pitäminen pysyi samalla tasolla kuin se oli yhdeksännellä luokalla. Yksittäisistä lukioon liittyvistä tekijöistä se, kuinka usein opiskeltavat asiat tulevat opiskelijoiden arvioimana selväksi, erotteli parhaiten poikien matematiikasta pitämisessä tapahtuneita muutoksia $(\mathrm{F}(1,72)=14,576 ; p=$ o,001). Erot muutoksessa kahden ryhmän välillä olivat noin 30 prosenttiyksikköä. Suurin osa pojista (noin 88 prosenttia) arvioi, että opiskeltavat asiat tulivat selväksi useammin kuin joskus ja heillä matematiikasta pitäminen kasvoi noin 11 prosenttiyksikköä.

Taulukossa 13 esitetään askeltavan regressioanalyysin tulokset parhaiden poikien matematiikasta pitämisessä tapahtuneisiin muutoksiin. Selittäviä tekijöitä löytyi sekä yläkoulun että lukion osalta. 
Taulukko 13. Poikien matematiikan pitämisessä tapahtuneita muutoksia yhdeksänneltä luokalta lukion loppuun selittävät tekijät askeltavan regressioanalyysin mukaan

\section{Muutoksen vaihtelu matematiikasta pitämisessä,}

pojat

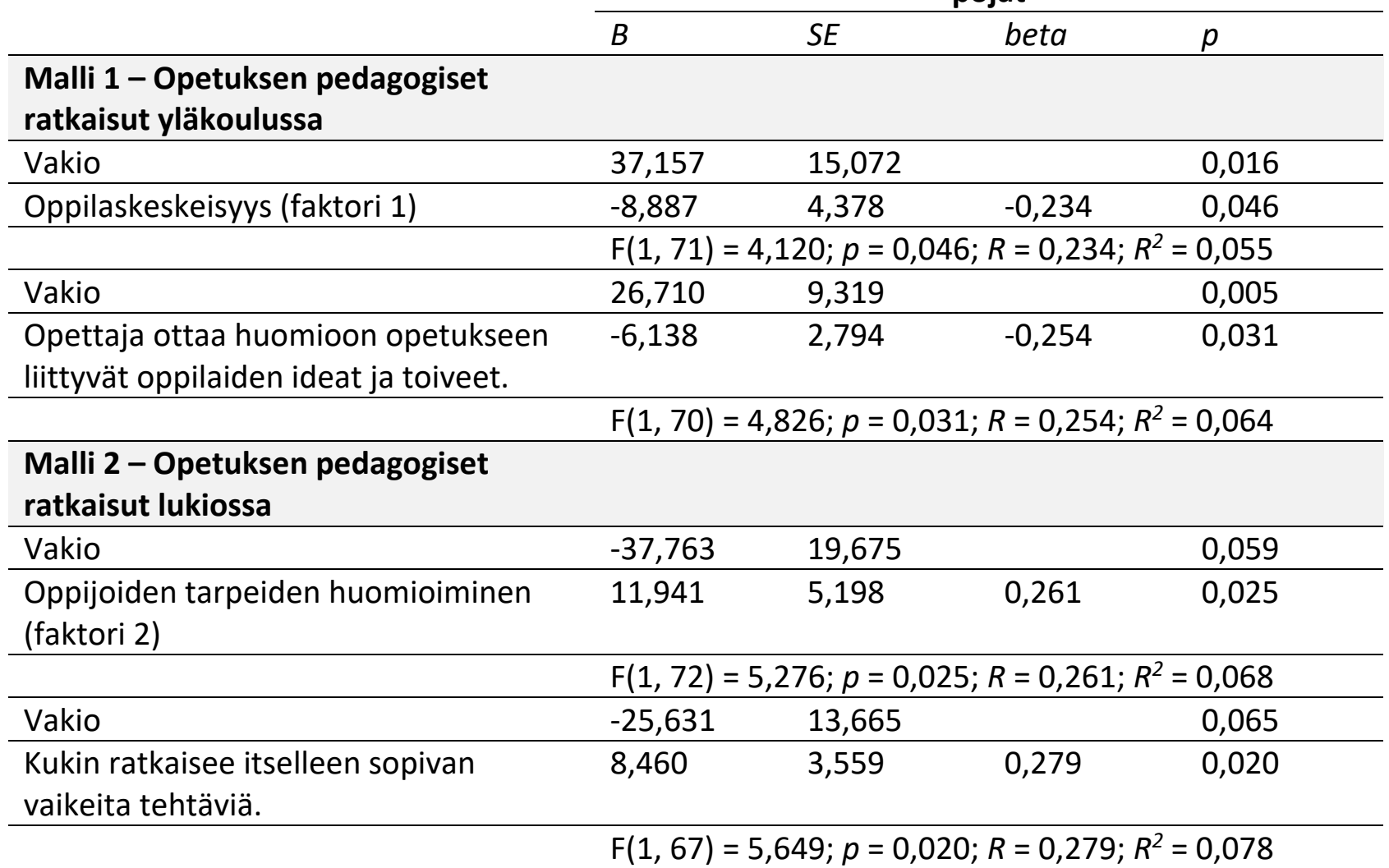

Tulosten mukaan yläkoulussa oppilaskeskeisyyteen liittyvät tekijät näyttivät heikentäneen pitämisessä tapahtuneita muutoksia samoin kuin se yksittäinen tekijä, jonka mukaan opettaja ottaa huomioon opetukseen liittyvät oppilaiden ideat ja toiveet. Koska näihin liittyvät muuttujat eivät vaikuttaneet malliin tilastollisesti merkitsevästi enää lukiossa, on todennäköistä, että parhaiden poikien matematiikasta pitäminen oli yhdeksännellä luokalla korkealla tasolla näiden tekijöiden selittäessä pitämistä. Kun näitä ratkaisuja ei toteutettu toistuvasti enää lukiossa, poikien matematiikasta pitäminen heikentyi.

Lukiossa parhaiden poikien matematiikasta pitäminen vahvistui, kun opetuksessa huomioitiin oppijoiden tarpeet. Se, että parhaat pojat ratkaisivat itselleen sopivan vaikeita tehtäviä, lisäsi heidän matematiikasta pitämistään.

Yhteenvetona voidaan todeta, että parhailla tytöillä monipuolisten opetusmenetelmien toistuvuus selitti matematiikasta pitämistä eri tavalla yläkoulussa ja lukiossa. Monipuolisten opetusmenetelmien toistuvuus yläkoulussa selitti korkeampaa matematiikasta pitämisen tasoa yläkoulun lopussa, mutta heikensi matematiikasta pitämistä lukiossa. Parhailla pojilla monipuolisten 
opetusmenetelmien lisääminen lukiossa ei näyttänyt vahvistaneen matematiikasta pitämistä. Poikien matematiikasta pitäminen kasvoi, kun opettaja huomioi opetuksessaan opiskelijoiden toiveita ja pojat saivat ratkaista itselleen sopivan vaikeita tehtäviä.

Matematiikan hyödyllisyys

Parhaiden tyttöjen matematiikan hyödyllisyyden kokemisen muutoksia selittäviä tekijöitä löytyi DTA-analyysilla sekä yläkoulun että lukion aikaisista tekijöistä (taulukko 14).

Taulukko 14. Tyttöjen matematiikan hyödyllisyyden kokemisessa tapahtuneita muutoksia yhdeksänneltä luokalta lukion loppuun erottelevat tekijät DTA-analyysin mukaan (tähdellä * merkitty muuttujien välinen yhteisvaikutus)

\begin{tabular}{llll}
\hline & $\begin{array}{l}\text { prosenttiosuus } \\
\text { parhaista tytöistä } \\
\text { (n= 55) }\end{array}$ & $\begin{array}{l}\text { muutos koetussa } \\
\text { toistuvuus } \\
\text { (asteikolla 1-5) }\end{array}$ & $\begin{array}{l}\text { matematiikan } \\
\text { hyödyllisyydessä } \\
\text { (prosenttiyksikköä) }\end{array}$ \\
\hline $\begin{array}{l}\text { Opetuksen pedagogiset ratkaisut } \\
\text { yläkoulussa }\end{array}$ & & \\
\hline $\begin{array}{l}\text { On yhteistä opetusta opettajan } \\
\text { johdolla. }\end{array}$ & 87,3 & $>3,0^{*}$ & $-5,9$ \\
\hline \multicolumn{1}{c}{$\begin{array}{l}\text { Annetut kotitehtävät olen } \\
\text { tehnyt sovitulla tavalla.* }\end{array}$} & 12,7 & $\leq 3,0$ & $-22,1$ \\
\hline $\begin{array}{l}\text { Opetuksen pedagogiset ratkaisut } \\
\text { lukiossa }\end{array}$ & 23,6 & $>4,0$ & $-9,1$ \\
\hline $\begin{array}{l}\text { Matematiikan yhteys käytäntöön } \\
\text { (faktori 1) }\end{array}$ & 69,1 & $\leq 4,0$ & $+2,7$ \\
\hline $\begin{array}{l}\text { Opiskellaan ryhmissä tai } \\
\text { pareittain. }\end{array}$ & 30,9 & & \\
\hline
\end{tabular}

Yläkoulun aikaisista yksittäisistä tekijöistä tytöillä muutosta hyödyllisyyden kokemisessa erotteli parhaiten se, että tunneilla on yhteistä opetusta opettajan johdolla $(\mathrm{F}(1,53)=7,508 ; p=0,017)$. Tytöistä noin 87 prosenttia arvioi yhteistä opetusta olleen useammin kuin joskus ja heillä koettu hyödyllisyys heikkeni noin 6 prosenttiyksikköä. Tytöistä niillä, jotka arvioivat yhteistä opetusta opettajan johdolla olleen joskus tai harvemmin, hyödyllisyyden kokeminen heikkeni noin 22 prosenttiyksikköä. Matematiikan hyödyllisyyden kokeminen kasvoi noin 3 prosenttiyksikköä, jos joskus tai useammin toistuvaan opettajajohtoisuuteen yhdistyi se, että oppilas teki annetut kotitehtävät sovitulla tavalla usein tai sitä harvemmin 
$(\mathrm{F}(1,46)=7,016 ; p=0,022)$. Sen sijaan jatkuva kotitehtävien tekeminen heikensi hyödyllisyyden kokemusta (muutos -9,1 prosenttiyksikköä).

Lukion aikaisista tekijöistä tyttöjen matematiikan hyödyllisyyden kokemisessa tapahtunutta muutosta erotteli parhaiten pedagogiset ratkaisut, joissa matematiikka yhdistyy käytäntöön $(\mathrm{F}(1,53)=8,381 ; p=0,027)$. Muutos oli vähemmän negatiivinen, jos matematiikkaa yhdistettiin käytäntöön ainakin harvoin. Ero ryhmään, jossa käytännön yhteyttä ei ollut lainkaan, oli noin 12 prosenttiyksikköä. Yksittäisistä tekijöistä hyödyllisyyden kokemisessa tapahtunutta muutosta erotteli opiskelu ryhmissä tai pareittain $(\mathrm{F}(1,53)=7,860 ; p=0,021)$. Noin 13 prosentilla tytöistä hyödyllisyyden kokemus kasvoi keskimäärin 6,4 prosenttiyksikköä, jos tunneilla opiskeltiin ryhmissä tai pareittain enemmän kuin joskus. Jos pari- ja ryhmätyöskentelyä oli joskus tai tätä harvemmin, kokemus matematiikan hyödyllisyydestä heikkeni noin 10 prosenttiyksikköä.

Taulukossa 15 ovat askeltavan regressioanalyysin tulokset, joista malliin jäivät vain lukio-opetukseen liittyvät pedagogiset ratkaisut.

Taulukko 15. Tyttöjen matematiikan hyödyllisyyden kokemisessa tapahtuneita muutoksia yhdeksänneltä luokalta lukion loppuun selittävät tekijät askeltavan regressioanalyysin mukaan

\begin{tabular}{|c|c|c|c|c|}
\hline & \multicolumn{4}{|c|}{$\begin{array}{c}\text { Muutoksen vaihtelu matematiikan hyödyllisyyden } \\
\text { kokemisessa, tytöt }\end{array}$} \\
\hline & $B$ & $S E$ & beta & $p$ \\
\hline \multicolumn{5}{|l|}{$\begin{array}{l}\text { Malli } 2 \text { - Opetuksen pedagogiset } \\
\text { ratkaisut lukiossa }\end{array}$} \\
\hline Vakio & $-26,667$ & 7,020 & & $<0,001$ \\
\hline \multirow[t]{2}{*}{$\begin{array}{l}\text { Matematiikan yhteys käytäntöön } \\
\text { (faktori 1) }\end{array}$} & 8,889 & 3,209 & 0,356 & 0,008 \\
\hline & \multicolumn{4}{|c|}{$\mathrm{F}(1,53)=7,675 ; p=0,008 ; R=0,356 ; R^{2}=0,126$} \\
\hline Vakio & $-39,238$ & 9,082 & & $<0,001$ \\
\hline $\begin{array}{l}\text { Sovelletaan matematiikan taitoja } \\
\text { arkielämän tilanteisiin. }\end{array}$ & 9,153 & 2,701 & 0,406 & 0,001 \\
\hline $\begin{array}{l}\text { Opiskelijat selittävät muille, miten } \\
\text { ovat tehtävänsä ratkaisseet. }\end{array}$ & 4,028 & 1,539 & 0,302 & 0,012 \\
\hline $\begin{array}{l}\text { Opiskelijat asettavat itselleen } \\
\text { tavoitteita ja arvioivat } \\
\text { edistymistään. }\end{array}$ & $-4,720$ & 1,684 & $-0,324$ & 0,007 \\
\hline \multirow[t]{2}{*}{ Opiskellaan ryhmissä tai pareittain. } & 4,191 & 2,037 & 0,246 & 0,045 \\
\hline & \multicolumn{4}{|c|}{$\begin{array}{l}\mathrm{F}(4,47)=7,487 ; p<0,001 ; R=0,624 ; R^{2}=0,389 \\
R_{A d j}^{2}=0,337\end{array}$} \\
\hline
\end{tabular}


Tulosten mukaan tyttöjen kokemus matematiikan hyödyllisyydestä vahvistui lukiossa, kun opetuksessa huomioitiin matematiikan yhteys käytäntöön. Tämä vahvistaa DTA-analyysin tuloksia. Yksittäisistä tekijöistä hyödyllisyyden kokemusta vahvisti eniten se, että matematiikan taitoja sovelletaan arkielämän tilanteisiin. Sen jälkeen hyödyllisyyden kokemisen kasvua selitti se, että opiskelijat selittävät muille, miten ovat tehtävänsä ratkaisseet ja opiskellaan ryhmissä tai pareittain. Omien tavoitteiden ja edistymisen arviointi näyttäisi heikentäneen hyödyllisyyden kokemusta.

Parhailla pojilla hyödyllisyyden kokemuksen muutoksia selittäviä tekijöitä löytyi vain askeltavassa regressioanalyysissa (taulukko 16).

Taulukko 16. Poikien matematiikan hyödyllisyyden kokemisessa tapahtuneita muutoksia yhdeksänneltä luokalta lukion loppuun selittävät tekijät askeltavan regressioanalyysin mukaan

\begin{tabular}{|c|c|c|c|c|}
\hline & \multicolumn{4}{|c|}{$\begin{array}{c}\text { Muutoksen vaihtelu matematiikan hyödyllisyyden } \\
\text { kokemisessa, pojat }\end{array}$} \\
\hline & B & SE & beta & $\mathrm{p}$ \\
\hline \multicolumn{5}{|l|}{$\begin{array}{l}\text { Malli } 1 \text { - Opetuksen pedagogiset } \\
\text { ratkaisut yläkoulussa }\end{array}$} \\
\hline Vakio & $-53,539$ & 20,559 & & 0,011 \\
\hline \multirow[t]{2}{*}{$\begin{array}{l}\text { Menestyminen kansallisessa kokeessa } \\
\text { (9.lk) }\end{array}$} & 0,067 & 0,029 & 0,264 & 0,024 \\
\hline & \multicolumn{4}{|c|}{$\mathrm{F}(1,71)=5,309 ; p=0,024 ; R=0,264 ; R^{2}=0,070$} \\
\hline \multicolumn{5}{|l|}{$\begin{array}{l}\text { Malli } 2 \text { - Opetuksen pedagogiset } \\
\text { ratkaisut lukiossa }\end{array}$} \\
\hline Vakio & 28,022 & 15,510 & & 0,075 \\
\hline \multirow[t]{2}{*}{ Opiskelijat neuvovat toisiaan. } & $-8,684$ & 3,695 & $-0,276$ & 0,022 \\
\hline & \multicolumn{4}{|c|}{$\mathrm{F}(1,67)=5,524 ; p=0,022 ; R=0,276 ; R^{2}=0,076$} \\
\hline
\end{tabular}

Pojilla matematiikan hyödyllisyyden kokemisessa tapahtunutta muutosta näyttäisi selittäneen parhaiten osaamisessa tapahtuneet muutokset. Lukiossa se, että opiskelijat neuvovat toisiaan, näyttäisi heikentäneen opiskelijoiden kokemuksia matematiikan hyödyllisyydestä.

Yhteenvetona voidaan todeta, että parhailla tytöillä muutoksen vaihtelua matematiikan hyödyllisyyden kokemisessa selitti parhaiten opetuksen pedagogiset ratkaisut, joissa matematiikan taitoja sovellettiin arkielämän tilanteisiin ja opiskelijat työskentelivät pareittain tai ryhmissä. Pojilla matematiikan hyödyllisyyden kokemisessa tapahtuneita muutoksia selittäviä tekijöitä ei juurikaan löytynyt. Heillä toisten neuvominen heikensi hyödyllisyyden kokemista. 


\section{Yhteenveto ja pohdintaa}

Tutkimuksessa selvitettiin ensin, miten matematiikan parhaiden osaajien matematiikkaan liittyvät asenteet muuttuvat perusopetuksesta lukion loppuun. Tulokset vahvistivat hypoteeseja. Ensinnäkin parhaiden osaajien matematiikasta pitäminen näytti heikkenevän jo kolmannelta luokalta kuudennelle kuten yleisesti muillakin oppilailla (Metsämuuronen, 2013). Parhailla osaajilla matematiikasta pitäminen pysyi kuitenkin yläkoululuokilla vakaana ja nivelvaiheen jälkeen yläkoulusta lukioon matematiikasta pitäminen kasvoi entisestään. Toisena tarkasteltavana asennetekijänä minäkäsitys pysyi parhailla osaajilla yläkoulun aikana vakaana ja korkealla tasolla, kun yleisesti oppilaiden minäkäsitys lähtee voimakkaaseen laskuun yläkoululuokkien aikana (Metsämuuronen, 2013). Kuitenkin myös parhailla osaajilla minäkäsityksessä tapahtui heikkenemistä lukiovuosien aikana. Big fish, little pond -efektin (Marsh ym., 2019; Holm ym., 2020) voidaan nähdä selittävän tätä ilmiötä. Parhaat osaajat kokevat olevansa parhaita yläkoulussa, kun vertailuryhmänä on koko ikäryhmään kuuluvat oppilaat. Opetusryhmä, johon oppilas kuuluu, on hyvin heterogeeninen. Vertailuryhmä kuitenkin muuttuu parhaiden osaajien siirtyessä toiselle asteelle. Lukioon hakeutuu koko ikäryhmästä reilu puolet ja pitkän matematiikan opinnoissa vertailuryhmä muuttuu yhä homogeenisemmäksi. Oppilas ei välttämättä koekaan olevansa enää ryhmän paras, kun ryhmän muutkin opiskelijat ovat hänen kanssaan samalla osaamistasolla. Toki minäkäsityksen heikkenemistä selittää varmasti myös se, että vaatimustaso lukioopinnoissa kasvaa ja myös parhaat osaajat joutuvat tekemään enemmän töitä osaamisensa eteen. Kolmantena asennetekijänä kokemus matematiikan hyödyllisyydestä heikkeni samansuuntaisesti kuin minäkäsitys, mutta heikkeneminen alkoi jo yläkoulun aikana. Vaikka kokemus matematiikan hyödyllisyydestä heikkeni, parhaat osaajat kokivat matematiikan hieman hyödyllisempänä kuin muut pitkän matematiikan kirjoittaneet opiskelijat. Menestys opinnoissa lisää varmastikin opiskelijoiden kokemusta matematiikan hyödyllisyydestä ( $\mathrm{Ma} \& \mathrm{Xu}, 2004)$ ja monella opinnoissaan erinomaisesti menestyvällä opiskelijalla on tavoitteena hakeutua alalle, jossa matematiikan osaamisella on keskeinen merkitys.

Parhaiden osaajien asenteita tarkastellessa on huomioitava, että matematiikassa parhaiten menestyneiden tyttöjen asenteissa tapahtuneet kehityssuunnat eroavat yleisestä kehityssunnasta. Yleisesti tytöt arvioivat olevansa poikia heikompia matematiikassa, vaikka matematiikan taidoissa ei olisikaan eroa (Cvencek ym., 2011; 
Lindberg ym., 2013). Käsitykset matematiikan osaamisesta laskevat tytöillä poikia voimakkaammin kouluvuosien edetessä ja sukupuolten välinen ero kasvaa (Lindberg ym., 2013). Tässä aineistossa matematiikassa parhaiten menestyneillä tytöillä käsitys itsestä matematiikan osaajana oli lähtötasoltaan kolmannella luokalla parhaiden poikien käsitystä selvästi heikommalla tasolla, mutta lähti kasvuun heti kolmannen luokan jälkeen ja ero parhaisiin poikiin kaventui yläkoulun aikana. Parhaiden tyttöjen ja poikien minäkäsityksessä ei ollut juurikaan eroa enää lukion lopussa. Muilla pitkän matematiikan kirjoittaneilla tytöillä minäkäsityksen ero poikiin pysyi yhtä suurena lukion loppuun asti. Myös matematiikasta pitämisessä tapahtuneet muutokset ovat kiinnostavia matematiikassa parhaiten menestyneiden tyttöjen osalta. Sekä parhailla tytöillä että pojilla matematiikasta pitäminen heikentyi kolmannelta luokalta kuudennelle. Tämän jälkeen pojilla matematiikasta pitäminen heikkeni vielä hieman yläkoulun aikana ennen kuin se lähti kasvuun lukio-opintojen aikana. Parhaat tytöt alkoivat pitää matematiikasta poikia enemmän kuudennen luokan jälkeen ja matematiikasta pitäminen kasvoi jyrkästi koko yläkoulun ja lukio-opintojen ajan eivätkä parhaat pojat saavuttaneet tyttöjen tasoa edes lukion lopussa.

Toiseksi tutkimuksessa selvitettiin, millaiset opetuksen pedagogiset ratkaisut selittävät tyttöjen ja poikien asenteissa tapahtuneita muutoksia. Selittäviä tekijöitä etsittiin regressioanalyysin ja DTA-analyysin avulla. Analyysimenetelmät täydentävät toisiaan, sillä regressioanalyysin avulla löydetään muuttujien välisiä lineaarisia yhteyksiä ja DTA-analyysi tunnistaa myös muuttujien väliset epälineaariset yhteydet. Tulosten analysoinnissa on kuitenkin huomioitava, että DTA-analyysin tekemät luokittelut eivät ole aina kovin vahvoja, koska löydetyt yhteydet saattavat näkyä vain pienellä osalla tutkimusjoukkoa. Asennemuutoksia selittäviä opetuksen pedagogisia ratkaisuja etsittiin sekä yläkoulun että lukion ajalta. Näiden vaikutukset asenteissa tapahtuneisiin muutoksiin olivat erilaiset. Yläkoulun aikaiset tekijät vaikuttivat oppilaiden asenteisiin yhdeksännen luokan lopussa eli muutoksen lähtötasoon ja lukion aikaiset tekijät oppilaiden asenteisiin lukion lopussa.

Tyttöjen ja poikien asenteiden kehittymistä selittävät erilaiset opetuksen pedagogiset ratkaisut. Molemmilla yleisesti myönteisiä asenteita vahvistivat oppilaskeskeisyyteen, yhteistoiminnallisuuteen ja oppijoiden tarpeiden huomioimiseen liittyvät tekijät aikaisempien tutkimustulosten (mm. Salmela-Aro, 2018; Hannula \& Oksanen, 2013; Salmela, 2016; Koskinen, 2016; Vanttaja, 2002) ja niihin perustuvan hypoteesin suuntaisesti. Sellaisten monipuolisten opetusmenetelmien käyttö, jossa yhdistyy muun muassa projektitöiden tekeminen tai 
konkreettisten välineidän käyttö, ei näytä edistävän myönteisten asenteiden kehittymistä.

Tulosten mukaan tytöillä minäkäsitystä vahvisti parhaiten palautteen saaminen omasta osaamisesta (testit ja kokeet sekä itsearviointi) ja kotitehtävien säännöllinen tekeminen. Tämä noudattaa Salmelan (2016) tuloksia laudaturylioppilaista, joiden opintomenestystä tuki opetus, jossa ilmeni palautteen antaminen ja kannustaminen. Pojilla minäkäsitystä vahvisti se, että he pääsivät selittämään muille, miten ovat tehtävänsä ratkaisseet ja se, että opiskeltiin pareittain tai ryhmissä. Tämä vastaa Hannulan ja Oksasen (2013) yläkoulua koskevia tutkimustuloksia yhteistoiminnallisten opetusmenetelmien suhteesta parempiin oppimistuloksiin. Tytöt tarvitsevat kannustusta ja vahvistusta uskoakseen itseensä ja poikien itsetunto kasvaa, kun he saavat näyttää osaamistaan muille.

Matematiikasta pitämisessä tapahtuneita muutoksia selitti osin samat tekijät sekä tytöillä että pojilla. Tytöillä monipuolisten opetusmenetelmien toistuvuus lukiossa heikensi matematiikasta pitämistä, mutta oli yläkoulussa yhteydessä parempaan asennoitumisen lähtötasoon. Lukiossa erityisesti projektitöiden tekeminen näyttäisi heikentäneen tyttöjen matematiikasta pitämistä. Myöskään pojilla monipuolisten opetusmenetelmien lisääminen lukiossa ei lisännyt matematiikasta pitämistä. Lukiossa opiskelun aikataulu on usein tiukka ja parhaat osaajat saattavat kokea projektitöiden tekemisen työlääksi ja aikaa vieväksi. Voi olla, että projektitöiden tekeminen aiheuttaa opiskelijoissa stressiä, jos he asettavat erityisen korkeat tavoitteet itselleen. Pojilla matematiikasta pitämistä näytti lisäävän oppilaskeskeisyyteen ja oppijoiden tarpeiden huomioimiseen liittyvät tekijät. Pojille oli tärkeää, että opiskeltavat asiat tulevat selväksi ja he saavat tehdä oman taitotasonsa mukaisia tehtäviä. Myös Salmelan (2016) mukaan opiskelijakeskeisyys oli yksi tekijä, joka ilmeni laudaturylioppilaiden opintomenestystä ja vahvuuksia tukevana opetuksen piirteenä.

Tytöillä matematiikan hyödyllisyyden kokemusta lisäsi opetuksen pedagogiset ratkaisut, joissa matematiikan taitoja sovellettiin arkielämän tilanteisiin. Myös yhteistoiminnalliset ratkaisut matematiikan soveltamisen ohella vahvistivat tyttöjen kokemusta matematiikan hyödyllisyydestä. Yhteistoiminnallisuus yhdessä käytäntöön liittyvän matematiikan kanssa tukee työelämässä tarvittavia valmiuksia. Pojilla ei löytynyt selkeitä opetukseen liittyviä ratkaisuja, jotka olisivat yhteydessä lisääntyvään kokemukseen matematiikan hyödyllisyydestä. 
Matematiikkaan liittyvien asenteiden vahvistaminen yläkoulussa ja lukiossa on tärkeää, jotta parhailla osaajilla kehittyy ja säilyy mielenkiinto matemaattisia aineita ja aloja kohtaan. Vahvaa matematiikan osaamista tarvitaan yhteiskunnan eri aloilla ja erityisesti tyttöjen mielenkiintoa matematiikkaa kohtaan tulee vahvistaa. Kuten tuloksissa havaittiin, matematiikan parhailla osaajilla ei ole lukion lopussa minäkäsitykseen liittyviä sukupuolieroja ja parhaat tytöt pitävät matematiikasta jo yläkoulussa parhaita poikia enemmän. Jotta asenteet matematiikkaa kohtaan pysyvät korkealla tasolla osaamisen kanssa, tarvitaan kannustamista, yhteistoiminnallisuutta ja oppijoiden yksilöllisiä tarpeita huomioivia opetuksellisia ratkaisuja. Projektitöiden teettämistä, tekemällä oppimista ja vastaavien opetusmenetelmien tarkoituksenmukaisuutta lukiossa tulee pohtia. Lisäksi jo yläkoulussa tulisi lisätä oppilaiden tietoisuutta matematiikan hyödyntämisestä yhteiskunnan eri alueilla ja ammateissa, jotta erityisesti tyttöjä saataisiin valitsemaan enemmän matemaattisia aineita jatko-opinnoissaan. Todennäköisesti jo korkeakoulujen matematiikkaa painottavalla todistusvalinnalla on ollut merkitystä sille, että tytöt ovat olleet motivoituneempia opiskelemaan matematiikkaa toisella asteella. Pitkän matematiikan kirjoittaneista suurin osa on jo toista vuotta peräkkäin tyttöjä (Ylioppilastutkintolautakunta, 2021).

On syytä ottaa huomioon, että tutkimus koskee vain matematiikassa parhaiten menestyneitä opiskelijoita, jotka ovat suorittaneet pitkän matematiikan ylioppilaskokeen ja tuloksia tulee tulkita heidän näkökulmastaan. On kuitenkin tärkeä muistaa, että myös muita kuin vain erinomaisesti matematiikassa menestyneitä osaajia tarvitaan laajasti yhteiskunnan eri aloilla ja tietoisuutta tästä tulisi lisätä myös lukio-opintojen aikana. Jatkossa olisi kiinnostavaa tutkia, voidaanko matematiikka-asenteita vahvistamalla lisätä myös keskitason osaajien halua opiskella enemmän matemaattisia aineita ja kykyä kasvattaa heidän omaa suoritustasoaan.

\section{Lähteet}

Bandura, A. (1986). Social foundations of thought and action: A social cognitive theory. Prentice hall.

Bloom, B. (1984). The 2 Sigma Problem: The Search of Methods of Group Instruction as Effective as One-to-One Tutoring. Educational Researcher, 13(6), 4-16.

https://doi.org/10.2307/1175554

Cohen, J. (1988). Statistical power analysis for the behavioral sciences. Erlbaum.

Cvencek, D., Meltzoff, A. N. \& Greenwald, A. G. (2011). Math-gender stereotypes in elementary school children. Child Development, 82(3), 766-779. https://doi.org/10.1111/j.1467-

8624.2010.01529.x 
Erdogan, A. \& Yemenli, E. (2019). Gifted students' attitudes towards mathematics: a qualitative multidimensional analysis. Asia Pacific Education Review, 20, 37-52.

https://doi.org/10.1007/s12564-018-9562-5

Fennema, E. \& Sherman, J. (1976). Fennema-Sherman Mathematics Attitudes Scales: Instruments designed to measure attitudes toward the learning of mathematics. Journal for Research in Mathematics Education, 7(5), 324-326. https://doi.org/10.2307/748467

Hannula, M. S., Bofah, E., Tuohilampi, L. \& Metsämuuronen, J. (2014). A longitudinal analysis of the relationship between mathematics-related affect and achievement in Finland. Teoksessa

S. Oesterle, P. Liljedahl, C. Nicol \& D. Allan (toim.), Proceedings of the Joint Meeting of PME 28 and $P M E-N A$ 36, 3, 249-256. PME.

Hannula, M. S. \& Laakso, J. (2011). The structure of mathematics related beliefs, attitudes and motivation among Finnish grade 4 and grade 8 students. Teoksessa B. Ubuz (toim.), Proceedings of the 35th Conference of the International Group for the Psychology of Mathematics Education, 3, 129-136. PME.

Hannula, M. S. \& Oksanen, S. (2013). Opettajamuuttujien yhteys osaamisen muutokseen. Teoksessa J. Metsämuuronen (toim.) Perusopetuksen matematiikan oppimistulosten pitkittäisarviointi vuosina 2005-2012. Koulutuksen seurantaraportit 2013:4.

Opetushallitus. Juvenes Print - Suomen yliopistopaino Oy, 253-294.

Holm, M., Korhonen, J., Laine, A., Björn, P. M. \& Hannula, M. S. (2020). Big-fish-little-pond effect on achievement emotions in relation to mathematics performance and gender. International Journal of Educational Research, 104. https://doi.org/10.1016/j.ijer.2020.101692

Jokivuori, P. \& Hietala R. (2007). Määrällisiä tarinoita. Monimuuttujamenetelmien käyttö ja tulkinta. WSOY.

Julin, S. \& Rautopuro, J. (2016). Läksyt tekijäänsä neuvovat. Perusopetuksen matematiikan oppimistulosten arviointi 9. vuosiluokalla 2015. Kansallinen koulutuksen arviointikeskus. Julkaisut 20:2016. Juvenes Print - Suomen Yliopistopaino Oy.

Kass, G. (1980). An exploratory technique for investigating large quantities of categorical data. Applied Statistics, 29(2), 119-127.

Koskinen, R. (2016). Mielekäs oppiminen matematiikan opetuksen lähtökohtana. Systemaattinen analyysi Journal for Research in Mathematics Education aikakauslehden artikkelien pohjalta. Helsingin yliopisto, Käyttäytymistieteellinen tiedekunta, Opettajankoulutuslaitos. Tutkimuksia 379.

Leikin, R. (2014). Giftedness and high ability in mathematics. Teoksessa S. Lerman (toim.) Encyclopedia of mathematics education. Springer Netherlands, 247-251. https://doi.org/10.1007/978-94-007-4978-8_65

Lindberg, S., Linkersdörfer, J., Ehm, J.-H., Hasselhorn, M. \& Lonnemann, J. (2013). Gender differences in children's math self-concept in the first years of elementary school. Journal of Education and Learning, 2, 1-8. https://doi.org/10.5539/jel.v2n3p1

Lord, F. M. \& Novick M. R. (1968). Statistical theories of Mental test Scores. Menlo Park.

Ma, X. \& Kishor, N. (1997). Assessing the relationship between attitude toward mathematics and achievement in mathematics: A meta-analyses. Journal for Research in Mathematics Education, 28(1), 26-47. https://doi.org/10.2307/749662

Ma, X. \& Xu, J. (2004). Determining the causal ordering between attitude toward mathematics and achievement in mathematics. American Journal of Education, 110(3), 256-280. https://doi.org/10.1086/383074

Marsh, H. W., Parker, P. D. \& Pekrun, R. (2019). Three paradoxical effects on academic selfconcept across countries, schools and students: Frame-of-reference as a unifying theoretical 
explanation. European Psychologist, 24, 231-242. https://doi.org/10.1027/10169040/a000332

Metsämuuronen, J. (2009). Metodit arvioinnin apuna. Perusopetuksen oppimistulosarviointien ja -seurantojen menetelmäratkaisut Opetushallituksessa. Oppimistulosten arviointi 1/2009. Opetushallitus.

Metsämuuronen, J. (2011). Tutkimuksen tekemisen perusteet ihmistieteissä: tutkijalaitos. Ekirjan 1. painos. International Methelp.

Metsämuuronen, J. (2013). Perusopetuksen matematiikan oppimistulosten pitkittäisarviointi vuosina 20O5-2012. Koulutuksen seurantaraportit 2013:4. Opetushallitus. Juvenes Print Suomen Yliopistopaino Oy.

Metsämuuronen, J. (2017). Oppia ikä kaikki - matematiikan osaaminen toisen asteen koulutuksen lopussa 2015. Kansallinen koulutuksen arviointikeskus. Julkaisut 1:2017. Juvenes Print - Suomen Yliopistopaino Oy.

Metsämuuronen, J. \& Tuohilampi, L. (2017). Matemaattinen osaaminen lukiokoulutuksen lopulla 2015. Kansallinen koulutuksen arviointikeskus. Julkaisut 3:2017. Juvenes Print - Suomen Yliopistopaino Oy.

Niemi, L., Metsämuuronen, J., Hannula, M. \& Laine, A. (2020). Matematiikan parhaaksi osaajaksi kehittyminen perusopetuksen aikana. Ainedidaktiikka, 4(1), 2-33.

https://doi.org/10.23988/ad.83384

Niemi, L. Metsämuuronen, J., Hannula, M. S. \& Laine, A. (2021). Matematiikan parhaiden osaajien siirtyminen toiselle asteelle: koulutusvalinnat ja matematiikan osaamisen kehittyminen. LUMAT: International Journal on Math, Science and Technology Education, 9(1), 457-494. https://doi.org/10.31129/LUMAT.9.1.1511

Ogbuehi, P. \& Fraser, B. (2007). Learning environment, attitudes and conceptual development associated with innovative strategies in middle-school mathematics. Learning environments research, 10(2), 101-114. https://doi.org/10.1007/s10984-007-9026-Z

Opetushallitus. (2003). Lukion opetussuunnitelman perusteet 2003. Nuorille tarkoitetun lukiokoulutuksen opetussuunnitelman perusteet. Määräys 33/011/2003. Opetushallitus.

Opetushallitus. (2004). Perusopetuksen opetussuunnitelman perusteet 2004. Opetushallitus.

Opetushallitus. (2009). Ammatillisen perustutkinnon perusteet. Lapsi-ja perhetyön koulutusohjelma/osaamisala. Määräys 18/011/2009. Opetushallitus.

Opetushallitus. (2014). Perusopetuksen opetussuunnitelman perusteet 2014. Määräykset ja ohjeet 2014: 96. Opetushallitus.

Opetushallitus. (2015). Lukion opetussuunnitelman perusteet. Määräykset ja ohjeet 2015: 48. Opetushallitus.

Opetushallitus. (2019). Lukion opetussuunnitelman perusteet. Määräykset ja ohjeet 2019: 2a. Opetushallitus.

Oppermann, E., Vinni-Laakso, J., Juuti, K., Loukomies, A. \& Salmela-Aro, K. (2021). Elementary school students' motivational profiles across Finnish language, mathematics and science: Longitudinal trajectories, gender differences and STEM aspirations. Contemporary Educational Psychology, 64(13), 101927. https://doi.org/10.1016/j.cedpsych.2020.101927

Rasch, G. (1960). Probabilistic models for some intelligence and attainment tests. Danmarks Pædagogishe in Mathematic Psychology I. Nielsen \& Lydiche.

Roesken, B., Hannula, M. \& Pehkonen, E. (2011). Dimensions of students' view of themselves as learners of mathematics. ZDM - The International Journal of Mathematics Education, 43(4), 497-506. https://doi.org/10.1007/s11858-011-0315-8

Ryan, R. \& Deci, E. (2017). Self-determination theory: Basic psychological needs in motivation, development and wellness. Guilford Press. 
Salmela, M. (2016). Tie ylioppilastutkinnon huippuarvosanoihin laudaturylioppilaiden kertomana. Lapin yliopisto.

Salmela-Aro, K. (2018). Motivaatio ja oppiminen kulkevat käsi kädessä. Teoksessa K. Salmela-Aro (toim.) Motivaatio ja oppiminen. PS-kustannus, 9-22.

Sternberg, R. J. \& Davidson, J. E. (toim.) (2005). Conceptions of giftedness. Cambridge University Press.

Tabachnick, B. G. \& Fidell, L. S. (2007). Using Multivariate Statistics. Fifth Edition. Pearson.

Tuohilampi, L. \& Hannula, M. (2013). Matematiikkaan liittyvien asenteiden kehitys sekä asenteiden ja osaamisen välinen vuorovaikutus 3,6 . ja 9. luokalla. Teoksessa J. Metsämuuronen (toim.), Perusopetuksen matematiikan oppimistulosten pitkittäisarviointi vuosina 2005-2012. Koulutuksen seurantaraportit 2013:4. Opetushallitus.

Vanttaja, M. (2002). Koulumenestyjät. Tutkimus laudaturylioppilaiden koulutus- ja työurista. Suomen kasvatustieteellinen seura.

Williams, T. \& Williams, K. (2010). Self-efficacy and performance in mathematics: Reciprocal determinism in 33 nations. Journal of Educational Psychology, 102(2), 453-466. https://doi.org/10.1037/ao017271

Ylioppilastutkintolautakunta (2021). Tilastoja ylioppilastutkinnosta. https://www.ylioppilastutkinto.fi/tietopalvelut/tilastot/tilastotaulukot. Luettu 30.5.2021. 